Western University Scholarship@Western

Political Economy Research Group. Papers in

Political Economy

Economics Working Papers Archive

1994

\title{
Making the Match: Domestic Placement Agencies and the Racialization of Women's Household Work
}

\author{
Abigail B. Bakan \\ Daiva K. Stasiulis
}

Follow this and additional works at: https://ir.lib.uwo.ca/economicsperg_ppe

Part of the Economics Commons

\section{Citation of this paper:}

Bakan, Abigail B., Daiva K. Stasiulis. "Making the Match: Domestic Placement Agencies and the Racialization of Women's Household Work." Political Economy Research Group. Papers in Political Economy, 55. London, ON: Department of Economics, University of Western Ontario (1994). 
POLITICAL

ECONOMY

RESEARCH

GR (O) U

\section{PAPERS IN POLITICAL ECONOMY}

Paper No. 55

"Making the Match: Domestic Placement Agencies and the Racialization of Women's Household Work"
Abigail B. Bakan and
Daiva K. Stasiulis

ECONOAICS REFERENCE CENTRE

$$
\text { JAN } 129995
$$

UWIUERSITY OF WESTERI OUTARIO 
The Political Economy Research Group was established in the faculty of Social Science at the University of Western Ontario in 1988. Its purpose is to foster scholarship, teaching and interdisciplinary research in political economy, with a focus on:

1. the application of economic models and methods to the study of political proçesses and institutions,

2. the economic impact of political processes and institutions,

3. the influence of economic factors on the formation of public policy and on institutional change,

4. the polities of economic policy making,

5. the political, social, and economic effects of public policy.

\section{Co-directors:}

Ronald Wintrobe (Economics)

Robèrt Young (Political Science)

\section{Board of Directors:}

Peter Howitt (Economics)

B.B. Kymilicka (Political Science)

John N. McDougall (Political Science)

Peter Neary (History)

John Whalley (Economics)

\section{Staff:}

Jayne Dewar

For further information:

Political Economy Research Group,

Department of Economics,

Social Science Centre,

London, Ontario, Canada N6A 5C2

phone: (519) 661-3877

fax: (519) $661-3292$ 
ISSN: $1181-7151$

ISBN: 0-7714-1724-1

40.58

Making the Match: Domestic Placement Agencies and the Racialization of Women's Household Work

By Abigail B. Bakan

Department of Political Studies

Queen's University

Kingston, Ontario

and

Daiva K. Stasiulis

Department of Sociology and Anthropology

Carleton University

Ottawa, Ontario

This paper will be published in a forthcoming issue of Signs: Journal of Women in Culture and Society.

Not for quotation without written permission from the authors. 
Making the Match: Domestic Placement Agencies and the

Racialization of Fomen's Household Fork

\author{
Introduction: Citizenship and Paid Domestic Labor
}

over recent years, there has been a notable shift in feminist scholarship regarding the study of women's labor in the home. While in the 1960s and 1970s, research focused on the significance for women's oppression of unpaid domestic labor, since the 1980 s more attention has been devoted to the role of paid domestic service in oppressing racial and ethnic minority, and working class women. The growing preoccupation with paid domestic labour reflects a transnational recognition among feminists that the employment of domestic workers in private households is a crucial nexus for structuring assymetrical race and class relations among women. 1 one dimension however that has

* We wish to thank Judith Adler Hellman, Radha Jhappan, and Yasmeen Abu-Laban for their helpful comments on a previous draft of this article. An earlier version of this paper was presented to the 16th Annual CRIAW Conference, "Making the Iinks: Anti-Racism and Feminism," November 13-15, 1992, Toronto, Ontario, Canada. We gratefully acknowledge the support of the Social sciences and Humanities Research Council of Canada and the Queen's University Advisory Research Council for funding the research for this project. The findings presented in this study are the result of a larger research project directed by the authors and entitled, "Women of Colour, Work and Citizenship: Filipino and West Indian Domestic Workers and Registered Nurses in Toronto." 1 see for example, Roger Sanjek and Shellee Colen (eds.), At Work in Homes: Household Workers in World Perspective (Washington DC: American Ethnological Society Monograph Series, 1990): Evelyn Nakano Glenn, Issei, Nisei, War Bride: Three Generations of Japanese American Women in Domestic Service (Philadelphia: Temple University Press, 1986); Judith Rollins, Between Women: Domestics and Their Employers (Philadelphia: Temple University Press, 1985); Phyllis Palmer, Domesticity and Dirt: Housewives and Domestic Servants in the United States, 1920-1945(Philadelphia: Temple University Press, 1989): Carol Groneman and Mary Beth Norton (eds.), "To Toil the Livelong Day": America's Women at Work, 1780-1980 (Ithaca: Cornell University Press, 1987): Cynthia Enloe, Bananas, Beaches and Bases: Making Feminist Sense of International Politics(Berkeley: University of 
not been adequately explored in this connection, and which this paper addresses, is the centrality of citizenship status as a determining and mediating factor in the entire matrix of relations pertaining to paid domestic labor on an international scale. As colen has noted, "there is a well documented relationship between migration and household work for all areas around the globe."2 citizenship is a pivotal element in understanding and analyzing the nature of this relationship. In particular, citizenship has cemented inequitable relations rooted in the global political economy and constructed through relations of race, gender and class, and has given these inequalities legal and ideological force.

In this paper, we argue that the nature, implications and structure of women's work in the home cannot be fully understood

California Press, 1989; 1990); Mary Romero, Maid in the U.S.A. (New York: Routledge, 1992); Daniel E. Sutherland, Americans and Their Servants: Domestic Service in the United States from 1800 to 1920 Baton Rouge: Louisiana University Press, 1981); Iinda Martin and Kerry Segrave, The Servant Problem: Domestic Workers in North America(Jefferson, NC: McFarland and Co., 1985; and Donna L. Van Raaphorst, Union Maids Not Wanted: Organizing Domestic Workers $1870-1940 \mathrm{~N}$ N York, Praeger, 1988). In reference specifically to the Canadian case, see Sedef Arat-Koc, "In the Privacy of our own Home: Foreign Domestic Workers as solution to the crisis in the Domestic Sphere in Canada," Studies in Political Economy 28, (Spring 1989): 33-58; Makeda Silvera, Silenced: Talks with Working Class Caribbean women About their Lives and Struggles as Domestic Workers in Canada 2nd edition (Toronto: Sister Vision;1989); Patricia M. Daenzer, "Ideology and the Formation of Migration Policy: The Case of Immigrant Domestic Workers, 1940-1990", Ph.D. dissertation (Department of Social Work, University of Toronto, 1991); Varpu Iindstrom-Best, " 'I Won't be a Slave!' Finnish Domestics in Canada, 1911-1930" in Jean Burnet, ed. ' Looking into My Sister's Eyes: An Exploration in Women's History(Toronto: The Multicultural Society of Ontario, 1986), 33-53; Agnes Calliste, "Canada's Immigration Policy and Domestics from the Caribbean: The Second Domestic scheme," Socialist Studies 5 (1989): and Audrey Macklin, "Foreign Domestic Worker: Surrogate Housewife or Mail order Servant?", McGill Law Journal, $37: 3$ (1992), 681-760. C Shellee Colen, "Housekeeping' for the Green Card: West Indian Household workers, the state and stratified Reproduction in New York," in Sanjek and Colen, (1990), 93. 
without addressing the relationship of citizenship statuses between female adult members of the household unit in "advanced"3 states, and female migrant domestic workers. The majority of those domestics who are employed are hired to look after children and perform basic housekeeping duties, "replacing" as it were, the labor normally expected to be performed on an unpaid basis by women in the private home. In developed capitalist societies, this work is usually performed by migrant women under the direct supervision of employed professional women. While migrant domestic workers lack many basic citizenship rights (including the right of choice of employer and domicile), their employers, in contrast, generally enjoy full citizenship rights. In the process of "matching" the increasing demand for in-home child care in developed capitalist states with a similarly increasing but highly regulated supply of unemployed Third world migrant women, citizenship rights are structured and mediated both across and within national boundaries.

The negotiation of citizenship rights involves a variety of structural and legislative restrictions in interaction with a distinct but parallel variety of individual and collective strategies. The interaction of these processes involves a range of "gatekeeping agencies" which serve to select, reject, and/or restrict the conditions of entry of female migrant domestic workers into developed states. The gatekeepers include state policy-makers and legislatures in both the home and receiving

3 our use of such terms as "advanced, "developed," "developing," "hegemonic," etc. to designate the economic status of given states in the global economy in no way accepts a ranking of states according to ethical or cultural criteria. Nor do we accept a static evolutionary schema of development, with a teleological goal of the "modern" state. We have retained these terms with the understanding that the development of Third world states has been blocked as a result of their economic relations with developed, imperialist states, and through an international system of economic and military competition that forces external priorities on the internal management of material and human resources. 
countries, government visa officers and other immigration personnel, professional accreditation bodies and educational institutions, and recruitment and placement agencies. These actors both individually and in interaction with each other also help structure the opportunities for future occupational trajectories and subsequent options for enjoyment of citizenship rights in the receiving countries. In addition, such agencies interpret information and influence future policy changes that have a direct impact on the social construction of "needs" and citizenship rights available to families in the advanced states.

one key gatekeeping industry that has received little attention in the literature, and which provides tine entry point for the discussion of citizenship presented here, is that of the private domestic placement agencies.4 Using the Canadian Live-in Caregiver Program as a case study, the centrality of citizenship status and the pivotal role of private domestic placement agents in negotiating citizenship rights and restrictions will be demonstrated.5 Rather than approaching "domestic labor" as an abstract category, universally similar for all women regardless of class, race, or citizenship status, the proposed alternative approach draws attention to the variations and limitations in

4 Only a few authors have addressed this subject. See Roxana $\mathrm{Ng}$, The Politics of Community Services: Immigrant Women, Class and State (Toronto: Garamond Press, 1988); Enloe, (1990), 183; Mary E. Devan, "Social, Economic and Political Factors Influencing the Supply and Demand of Foreign Domestic Workers," MA Thesis (Department of Anthropology and Sociology, University of British Columbia, 1989); Martin and Segrave (1985), 94-127; and, for a journalistic account, Claire Gerus, "The Business of Bringing Up Baby," The Financial Post Magazine (April 30, 1981), 28-33. 5 To be eligible by Canadian law to hire a domestic on the Live-in Caregiver Program (LCP), or under its predecessor program, the Foreign Domestic Movement (FDM), the family must indicate that they are able to provide a room in their home, for which rent would be deducted from wages earned, and a minimum combined annual income. As of April of 1992, that minimum in ontario was approximately $\$ 65,000.00$ per year, about $\$ 20,000.00$ above the national combined average annual family income. See Estanislao Oziewicz, "Nanny Policy Called Necessary Protection," Globe and Mail, (April 29, 1992). 
the options available to women with differing citizenship statuses. 6

This paper explores the ideological and allocative activities of one set of gatekeepers: domestic placement agencies which specialize in the recruitment and placing of migrant domestic workers into private family households. The analysis is based largely on intensive qualitative interviews with ten of the leading and most established domestic placement agencies in Toronto, ontario. 7 The analysis illuminates the influential role of these gatekeepers in reproducing a highly racialized set of practices and criteria in the recruitment and placement of female migrant domestic workers in upper income Canadian households.

The method of elaboration relies extensively on direct quotation, analytically contextualized to reveal the central

6 For an insightful summary of the problems of universalizing household labor, and the alternative value of viewing household work "historically, locally and contextually within a world capitalist system," see Shellee colen and Roger Sanjek, "At Work in Homes II: Directions," in Colen and Sanjek (1990), 176-188.

7 Additionally, the authors observed several national and international meetings and conferences organized by placement agencies, and consulted a wide variety of policy documents and secondary sources. The domestic placement agency industry is extremely volatile. As small, often single family or single employee businesses, agencies open and close frequently, particularly in times of economic instability such as the present. Moreover, in Canada, only three of ten provinces, ontario, Quebec and British Columbia require licensing. The agencies selected for interviewing in this case study were all licensed, reputable and well established agencies with two or more years of successful operation in the industry. While all of the agencies interviewed did some overseas recruitment, in light of recessionary conditions they also placed foreign domestics already resident in Canada on temporary status employment authorizations. All serviced the area of Toronto and vicinity, where the largest concentration in the country of in-home legally documented foreign domestics are employed. There are, however, numerous unlicensed agencies operating within those provinces that require licensure, witnessed by a glance at any daily newspaper across Canada. See "Newspaper Ads Photocopies File: 1988-92," compiled by Judy Richards. 
gatekeeping role of the domestic placement industry in regulating citizenship practices and ideologies. It is our belief that their strategic role in influencing and administering citizenship practices in canada and internationally is best explained by allowing the gatekeepers to speak for themselves. While it is not suggested that the sample presented here is statistically representative, the relations that are brought to light are analytically reflective of wider processes which are structural and systemic. 8

This perspective demands not only a recasting of the concept of domestic labor, away from universalistic models, but also a reconsideration of "citizenship" as an analytical category. Citizenship, like the private household, has been considered in most of the existing literature to be based on a narrow definition of rights and privileges associated only with one type of state the developed capitalist state, hegemonic in the world order of states and state relations.9 In contrast to this conception of citizenship as the property of nation-states, we view citizenship within a global framework, in which nationstates play a mediating role, establishing the rules governing entry, exit and settlement, as well as access to whole sets of civil, political and social entitlements.

Viewing citizenship in a global context, mediated by nation-states, opens up an understanding of the range of unequal citizenship statuses that are continually negotiated and reproduced within contemporary liberal democratic states, and

8 For a discussion of the value of "intensive" qualitative methods such as structural and causal analysis, participant observation and/or informal and interactive interviews, see Andrew Sayer, Method in Social Science: A Realist Approach (London: Hutchison, 1984), 221 ff.

9 See for example, Bryan S. Turner, "Outline of a Theory of Citizenship," Sociology 24, 1990: 189-217; Iris Marion Young, Justice and the Politics of Difference(Princeton: Princeton University Press, 1990); and Desmond S. King and Jeremy Waldron, "Citizenship, Social Citizenship and Defence of Welfare Provision," British Journal of Political Sciencel8, $1989: 415-443$ 
which are continually challenged by those who are accorded the most limited rights. The construction and dissemination of racialized and gendered stereotypes aid in demarcating various gradations of citizenship statuses.

In the following discussion, the various elements which together comprise the processes through which such stereotypes are created and re-created will be explored. The argument proceeds by considering each element separately, but the intention is to indicate linkages rather than suggesting autonomous processes. Moving from an examination of the socially and politically constructed "need" for live-in domestic care and the specific "match-making" role of domestic placement agencies, a detailed look at the stereotyping process to which Third world women domestic workers are subjected is presented. This is followed by a consideration of the predominant class interests that underlie the matching activity. Finally, the argument turns from the stereotyped definitions of reality to the actual conditions of poverty and underdevelopment which compel Third world women to apply for, and to accept, in-home domestic service in First world countries. In the conclusion, some of the broader implications for the feminist study of "difference" are drawn from our examination of household labor, gatekeepers and citizenship.

\section{Iive-in Domestic Care and the "Need" for a Natch-maker}

With increasing employment of women outside the home, and the growing dependence of family earnings upon two adult incomes, what has been described as the "crisis in the domestic sphere" has increased.10 thile women wait longer to have children and have smaller families, the demand for publicly supported and fully funded quality child care has increased.11

10 Arat-Koc (1989), $34 \mathrm{ff.}$

11 Canada lacks a comprehensive and equitable federal child care policy to ensure reasonable access to regulated child care. The national government has largely limited its 
Thus, while the number of regulated child care spaces in Canada had jumped an impressive 600 percent, from 55,181 in 1974 to 333,082 in 1991, there were nonetheless 800,000 more children in 1991 who were not in regulated care than there had been eighteen years previously.12 As Jane Beach indicates, the vast majority of children in alternative arrangements are cared for in the unregulated sector. Of these, approximately half are cared for by relatives, and the rest by caregivers baby-sitters and nannies. The latter form of care takes place either in the child's own home, the home of another child, or the home of the provider.13

A variety of factors contribute to the decision of parents to seek live-in care for their pre-school children. These include the high fees of regulated care, exceeding $\$ 1,000$ per month for infants in some parts of canada, the difficulty in obtaining subsidized daycare spaces, and the limited access to subsidies of middle-income families.14 A further factor in determining the option to hire a live-in nanny is the irregular working hours of a large proportion of working parents. Public childcare is commonly available only to parents who work a five-

involvement in child care to a number of funding mechanisms, such as the Canada Assistance Plan (CAP). The fact that in 1990, the federal government placed limits on the annual increases to CAP has further exacerbated the regional differences in income level eligibility for child care subsidies, and the amounts of these subsidies. See Mab oloman, "Child Care Funding," Strategy paper for National Child Care Conference \& Lobby, Ottawa, October 1992, 4 . See also The Task Force on Child Care, Report of the Task Force on Child Care (Ottawa: 1986); Ruth K. Abbott and R. A. Young, "Cynical and Deliberate Manipulation? Child Care and the Reserve Army of Female Labour in Canada," Journal of Canadian Studies 2, vol. 24 (Summer, 1989): 22-38; Dawn Currie, "Rethinking What we Do and How we Do it: A Study of Reproductive Decisions," The Canadian Review of Sociology and Anthropology 25,2 (May 1988): 231-253.

I2' Jane Beach, "A Comprehensive system of Child Care," strate? paper for National Child Care Conference \& Lobby, Ottawa: October 1992,7 .

13 Ibia., 9 .

14 Ibid. 
day week, Monday to Friday, from nine to five. According to a 1988 National Child Care Study for Canada, however, 44 per cent of interviewed parents did not work a standard work week. 15 Parents who work in the evenings or weekends, or whose working hours vary from week to week or day to day, find little support in the services available through public childcare.

The difficulty of raising small children while both parents continue to work full time outside the home, and the increasing number of single-parent families, have contributed to a growing demand for full-time live-in caregivers in canada as in other developed Western states. In both Canada and the US, the demand for live-in nannies is growing.16 However, because of the poor working conditions associated with live-in care, workers in advanced states who seek this source of employment are scarce.17

15 Cited in Ibid.

16 This is in part a result of government inaction on public demands for quality, publicly supported daycare centres for pre-school and school age children. See Susan Prentice, "'Kids are Not for Profit': The Politics of Childcare," in Social Movements/Social Change: The Politics and Practice of organizing, Frank Cunningham, et al (eds.), (Toronto: Between the Lines and the Society for Socialist Studies, 1990): 98128. For a statistical profile of the recent increase in demand for live-in care in Canada, see "Statistical profiles and Forecasts of the Foreign Domestic Movement: Summary", Research Division of the Strategic Planning and Research Directorate, Employment and Immigration Canada (November 1990). On the demand for in-home care in the US, see Katrine Ames, et al, "Wanted: Mary Poppins," Newsweek (January 27, 1992): 50-1; Cathie Robertson, "President's Message", INA Quarterly 3, vol. 2 (Spring 1991). IT The demand for live-in domestic care has arisen periodically, in different historical and socio-economic contexts. In each case, however, live-in work is accepted when alternative sources of employment are unavailable to a given segment of women, usually women or colour who experience both gender and racial bias in employment access. Regarding the Us example, see Elizabeth Clark-Lewis, "This Work Had a End': African-American Domestic Workers in Washington, DC, 1910-1940," and Vicki L. Ruiz, "By the Day or Week: Mexicana Domestic Workers in El Paso," in Groneman and Norton (1987); Colen in Colen and Sanjek (1990); and Glenn (1986). For examples drawn from Third World regions, see Sanjek and Colen (1990). 
Further, in recent years an ideological argument, characteristic of a general backlash against feminism and women's rights, has tended to discredit public childcare. There is no basis in fact to the claim that public child care risks the emotional or physical development of healthy children. On the contrary, the most rigorous studies conducted to date have indicated quite the opposite.18 However, the increasing legitimacy of the idea that private in-home childcare is the best quality care available is an important element in the growth of demand for in-home childcare in advanced societies.19

18 one of the most systematic studies in the united states conducted over a three year period by the University of New Hampshire's Family Research Laboratory concluded in 1988 that there was no epidemic of child abuse in daycare centres in the US, despite media claims to the contrary. In fact, private homes were cited as far more dangerous for children. See Susan Faludi, Backlash: The Undeclared War Against American Women (New York: Crown Publishers, 1991), 42-3. Another comparative study of child care quality in Canada, the US, England, Western Europe, Bermuda and New Zealand concluded that quality working conditions for child care staff and a low child/adult ratio are the critical determinants in assessing good care. For these findings see Gillian Doherty, Quality Matters in Child Care (Huntsville: Jesmond Publishing, 1991).

19 In the US, New Right idealogues labelled day care "the Thalidomide of the " 80 s" and horror stories of abuse, molestation and diseases spreading in public childcare facilities became rampant in the media. The 1992 Republican Party convention's adoption of a program committed to the assertion of "family values" continued in the same vein. In Canada, media headlines reporting "June Cleaver-style Moms Back in Fashion" have coincided with the emergence to national prominence of the Reform Party, a far-right populist political party. The influence of the Reform Party has been apparent in the efforts of the governing Progressive Conservative Party (Tories) to accommodate to Reform's "family values" agenda. A caucus of 35 high ranking Tory Members of Parliament, organized in the "Committee for Family Issues" was largely responsible for ensuring the reversal in February 1992 of an eight year commitment to a federal daycare program. See Faludi (1991); Marilyn French, The war Against Women (New York: Summit Books, 1992), 137-8; Allana Mitchell, The Toronto Globe and Mail April 20, 1992; and "Our Families Come First: Why More Mothers are Choosing to stay at Home," Chatelaine Magazine February, 1992. 
Domestic placement agencies have both promoted and benefited from the results of the backlash and the rise of parental fears. The private domestic placement agency is fundamentally a 'middle-man' between parent-employers and caregivers, or more precisely, a 'middle-woman,' since the available evidence suggests that a majority of these businesses are owned and managed by women. 20 such agencies serve to "match" the demand for private in-home care from among the available applicants of nannies, domestics and/or housekeepers. As one agency owner put it, "Making a placement in a client's home is almost like a marriage. It has to fit."2l the notion of an arranged marriage is a suitable analogy; the oppressive

The ideological backlash against public daycare, has also been accompanied by horror stories of the untrustworthy nanny. One of the most popular movies released in the winter of 1992 was The Hand that Rocks the cradle (Hollywood Pictures; Directed by Curtis Hanson) which featured a psychopathic nanny who attempts to murder her employer and kidnap the children. It should be noted that the nanny portrayed in the movie was atypically upper class, and was motivated by revenge for her husband's suicide. But the true story of the death of three-month old Kristie Fischer, whose Swiss nanny, 20 year old Olivia Riner was charged by police for murder and arson in the Thornwood New York home, could only increase the fears of parents regarding the quality of live-in child care. (Ames, et al, January 27, 1992, 50). One company, Brown-McComas Child Care Management Resources, based in Duncanville, Texas markets a "Child Care screening System" to domestic placement agencies that includes a software program called the Child Abuse Inventory Potential (CAP). The system is advertised to measure "an applicant's attitudes that exhaustive research and theory have proven to be associated with physical abuse." Brochure produced by BrownMcComas Child Care Management Resources, n.d. 20 In the United States, the major national organization of domestic placement agencies also includes nannies and professional childcare educators as its major constituencies. The International Nanny Association (INA), registers among its placement agencies a large majority of female owneroperators. In Canada, the Canadian Coalition for In-Home Child and Domestic Care is an analogous organization, though one less explicitly committed to promoting quality childcare as its principal mandate. The majority of its agency membership is similarly comprised by women owner-operators. 21 Interview, October 2, 1991, A. Bakan with Agency "C" 
conditions of such marriage also imply the "need" for a masterful match-maker. Another agency owner used a different analogy to make the same point, stating that, "Getting a nanny is like getting a custom-made dress. You don't just take it off the rack. "22

One of the critical tasks undertaken by the domestic placement agency is the screening of potential employees to ensure the most appropriate match for the employer. Should the employer feel sufficiently confident and capable of performing such a selection process independently, the need for the agency's services immediately disappears. Part of the role of the agency is therefore actually to manufacture greater demand, impressing upon potential clients the need for professional screening. 23

In Canada, the federal legislation regulating the recruitment of in-home domestic care, the Live-in Caregiver Program (LCP), was formulated to facilitate and regulate the recruitment of migrant workers. The policy is designed to fill a labor market deriand which, in the absence of foreign recruitment, is widely acknowledged to be virtually impossible to fill even during periods of high unemployment. The law requires that foreign domestics have a valid offer of full-time, live-in employment prior to entry into the country. Moreover, for a minimum of two years from the date of arrival in Canada, the foreign domestic worker is granted only temporary resident status in the country. This status is subject to termination; in

22 Interview, October 6, 1992, A. Bakan with Agency " $K$ "

23 Agencies are not, of course, the only group with an interest in careful screening. Parent support movements and childcare advocates similarly argue for careful selection processes to be followed, in part in response to the low status normally assigned to in-home childcare. See Barbara Kaiser and Judy Sklar Rasminsky, The Daycare Handbook: A Parents' Guide to Finding and Reeping Quality Daycare in Canada (Toronto: Little, Brown and Co., 1991): 34-50; and "Nanny Placement Practices in America: Preliminary Survey Results," National Nanny Newsletter 3, vol. 4 (Fall 1988): 811. 
the event that the worker's employment is terminated and the work permit is withdrawn, the domestic worker is subject to deportation. Therefore, domestic placement agencies also serve to access the Canadian labor market for immigrant labor.

The screening process involves rendering a selection which is both structurally global, and at the same time prone to a wide spectrum of interpretive and culturally idiosyncratic criteria. Hence, the perspective of the agency in terms of what "Canadian families need" can be highly influential, not only in perpetuating racial/ethnic and gendered stereotypes, but also in determining the overall quantity and "desirable" source countries of female domestic immigration.

one highly reputed agency owner summarized her company's success as follows:

Our philosophy is "quality childcare." The average Canadian child is poorly mannered and poorly brought up. Unless the parents are lucky enough to have had European parents who are more strict.... And the school system isn't helping here either. They have these routines in Europe, but here it's one big Montessori school. You take a spoiled Canadian child, a stressed-out family, and a Third world woman from a laid-back culture. That's a recipe for trouble. 24

Another agency owner arrived at the same conclusion about the desirability of European caregivers:

A lot of families would like a European, with a culture and standard of living similar to their own. They don't want someone who wants to be a nanny all her life. It's a good way for other cultures to learn to speak the language.... I don't want to sound prejudiced, because I'm not. But

24 Interview, November 22, 1991, A. Bakan with Agency "G" 
Canadians are well, culturally more educated,
different. 25

Assessing the quality of childcare in terms of the nationality or 'race' of the childcare giver is a standard feature of the matching process. Because childcare is considered to be "woman's work" in Canada as well as internationally, the assumption is that it is a skill that requires little formal training. Rather, a "very special" combination of "natural" characteristics is usually called for. Racialized stereotypes prevail, both in terms of interpreting the "needs" of the employers and in shaping the projected charact prospective employees. The normal procedure is for agencies to be paid by the employer on the completion of a successful placement, usually at the rate of one month's salary and backed by a three to six month guarantee to replace the domestic if the employer is not fully satisfied. It is therefore not surprising that the agencies interviewed universally indicated that their economic success was based on carefully meeting a highly racially and ethnically-sensitive, and stereotyped, client market. A few examples illustrate the allocative role of racial and ethnic stereotypes in the selection process.

I'm not prejudiced at all, but if a family says they don't want someone who speaks Chinese, I can't place someone in their home who is chinese. We are different as domestic placement agencies from other types of employment agencies. We are dealing with the right of families to have someone live-in, and to raise their children.26

Another agency owner put it this way:

25 Interview, May 21, 1991, A. Bakan and D. Stasiulis with Agency "H"

26 Ibid. 
I cannot say this, I know, because I could be charged for this under the Human Rights code. But let me give you an example of this business. I have a client, a man, who said that he couldn't stand the hairdo of a girl I sent to him for an interview. He couldn't stand to look at her on a daily basis with that hairdo. He had nothing against Blacks, but it was all in little braids, and he hates that. His wife wanted to hire her. He and his wife had a terrible fight over it... The couple called me up because they were arguing. I said, "I know you want her, but $I$ won't recommend her. Because it's not fair to you, and it's not fair to the girl." His wife was angry with me for taking his side, but that's how I see it. 27

The most commercially successful agencies also screen prospective clients. The premise is that the most suitable employers for live-in domestic workers will likely return to them for replacement positions, refer the agency to their friends, and be the least likely to complain about the selection they have received. Who is considered a "good employer" is also determined by pre-conceived notions of "good childcare" within the private family. Some statements of agency owners illustrate this point:

I am stunned by what Canadian women are willing to settle for in childcare. They don't check references. They worry that girls may be stealing or whatever, and I say, "Well aren't you worried about the quality of childcare?" People are more worried about whether their property is being stolen than about how their kids are being cared for. If

27 Interview, october 1, 1991, A. Bakan with Agency "C." All of the placement agencies interviewed routinely referred to the domestic workers as "girls," regardless of their actual age, while female employers were never referred to using this term. The class and racially specific gender stereotyping in this linguistic differentiation is obvious. On the role of linguistic deference in the domestic/employer relationship, see Rollins (1985), 158ff. 
you are looking for a slave, you are not an ideal employer. A nanny is a human being, and she is looking after your most precious possession, your children. I ask the employers, "What is going to suffer? will it be the childcare or the housework?"128

And:

We spend a lot of time talking to the families.... We screen the families as well as the girls. Lots of times we turn down families as placements. The families that appeal to us are usually ones with shared responsibilities. We meet with all the families before we place... We do a lot of work with new parents. If we can get them, we have them for several years while the child is young, and they may have more children. Also, they're fresh. We can educate them.29

The criteria of selection of suitable employers are often entirely subjectively determined, without even the pretence of a formal procedure. Some agencies screen simply on the basis of an initial telephone inquiry, or even a message left on an answering machine.

The employers do not have a clue about how to supervise a nanny, as you would for example a clerk or a secretary. I can usually tell which clients I should concentrate on. If I am extremely busy, I may not even have the time to phone back and say that I can't help you. 30

Moreover, the time spent screening potential employers is considerably shorter, and the quality of the perusal more superficial, than that spent selecting employees. The scrutiny of the gatekeepers is therefore not a balanced or neutral

28 Interview, October 23, 1991, A. Bakan with Agency "E"

29 Interview, November 22, 1991, A. Bakan with Agency "G"

30 Interview, November 6, 1991 , A. Bakan with Agency " $F$ " 
process, despite the claim advertised to the contrary throughout the industry. The imperative of the agencies is to find a placement suitable to a pre-conceived, ideologically constructed ideal "Canadian" family, from among a pool of applicants, similarly pre-conceived and treated with suspicion as unlikely candidates. To the extent that clients are screened by the agencies, the emphasis is on the approach and attitudes regarding childcare and "family values." Attention is also paid to economic issues, such as the capacity to pay the minimum expected wages and the provision of a private room required in the Canadian legislation.

Not only are the parties subject to differential scrutiny by the placement agencies; they are also entitled to differential rights of scrutiny of their prospective matches. Here, again the analogy between live-in domestic workers, or "mail order servants" 31 and "mail order brides", is relevant. In both types of an arranged "match," the scrutiny offered to the resident citizen is at a premium, whereas the non-citizen, female applicant, is entitled to no such selection procedure regarding her future. The opportunity to scrutinize the application of the prospective live-in domestic, like the prospective "bride", is virtually unlimited; in contrast, the opportunity of the applicant to obtain information regarding a future employer or "husband" is virtually nonexistent.

31 Macklin (1992), 681. There is evidence to suggest a fairly extensive mail-order bride service currently in operation, drawing particularly among Filipino women in search of permanent residency in Canada. This practice exists in the netherworld between legal and illegal immigration activities. once legal marriage is intended, a Canadian citizen can apply to legally sponsor their spouse to enter the country as a landed immigrant, or permanent resident. However, the "arrangement" of such marriages is usually mediated by coercive measures, at a price, by illegal mediators. In some countries, such as Japan, the entry of Filipino women under such circumstances is largely controlled by the criminal underworld. See Naomi Hosoda, "The Japayuki Phenomenon in the 1980s: The Process of Incorporating Filipino women into the Japanese Entertainment Industry," (unpublished ms.: 1993) 
Unlike the phenomenon of an actual arranged marriage, however, the live-in domestic is usually expected to work as a professional caregiver for young children. A host of contradictory pressures combine in the matching process which relate to the genuine need for trained professional childcare on the one hand, and the low status of live-in care on the other. The work involves long hours, low remuneration, little job control or employee protection. It is also socially isolating and highly prone to employer abuse. Canadian workers, or any non-citizen workers in canada with access to the wider labor market, generally do not apply for live-in work in private family homes. The available applicant supply is largely of Third World origin a reflection of the unequal global relations between Canada and Third world states, as well as the low status associated with childcare provision in general, and in-home childcare in particular.32

32 The low status of live-in care is also a feature of the US context. However, since the enactment in 1986 of highly restrictive immigration policies associated with the hiring of undocumented workers, there has been greater pressure to train professional nannies who are us citizens. The following extract from a letter dated "January 1989 " and signed by Joanne Kobar, President of TGIF Peopleworks, Inc., a nationwide US "domestic help search franchisor," explains clearly the impact of the 1986 legislation on in-home care and the recruitment of immigrant labour. The letter was sent to members of the US Congress and senate to lobby for a change in the law as it applies to in-home care. It was received by the authors courtesy of Deborah Davis, Ph. D., editor of the National Nanny Newsletter:

"Home employers and employment agencies who find their household help would heartily welcome a work permit to be granted to those aliens who commit themselves to in-home employment, such permit for a particular duration (maybe two to five years). So long as the alien is employed in this capacity, they could not be deported; if they strayed, they would be immediately subject to deportation.

"Prior to the passage of the Immigration Reform and Control Act of 1986, this proposed bill included a clause which specifically excluded private families employing less than three in-home employees; in other words, it would still be ok for a family to have an illegal alien working as a household employee (housekeeper, nanny, eldercare companion), and no penalties would be brought against the employer or the 
Agencies respond in two diametrically opposed ways to the predominance of Third world migrant women among foreign domestic workers. The first is that paid domestic work is not suitable for "Canadian" women.

If there is a canadian applicant for a domestic job, then you are doing something wrong. Canadian applicants are nonexistent. Maybe one in five months will be a Canadian, usually a mature woman. 33

This perspective also presumes that non-Canadians, specifically migrant women of color, are inherently suitable to perform domestic service. An earlier government program, almost identical to the Live-in Caregiver Program titled the Foreign Domestic Movement (FDM), was in operation from 1981 to 1991. Unlike the LCP, however, the earlier policy required that domestics upgrade their skills upon arrival in canada in order to be eligible for permanent resident status in the country. 34

employee. However, interestingly, this clause never appeared in the passed Immigration Act.

"... Constant advertising never brings enough job applicants to fill the demand, and families don't know where to turn. Calls come into our offices daily from undocumented aliens who are experienced as domestic workers and wish to be employed, and we have to turn them away, knowing that we could have filled their needs ten times with desperate families crying for such help.

"The illegal domestic worker is not stealing jobs away from Americans; the American employees have priced themselves way beyond the reach of the average household employer, and usually don't even bother to respond to advertisements for this type of employment. The undocumented worker does not have as many living expenses to meet as the American, and so asks for a wage which is much more affordable to the alreadystrapped American family. (sic)..." See also Gitta Morris, "In-Home Help: Matching Needs," New York Times, Sunday, August 2, 1987

33 Interview, september 26, 1991, A. Bakan with Agency "B" 34 The main features distinguishing the new Live-in Caregiver Program from the FDM were the heightened educational and formal training requirements as entrance criteria, and the removal of upgrading and other eligibility requirements for obtaining permanent resident status. The shared features of 
obtaining permanent immigration status would commonly mean leaving live-in domestic work, as other employment options became legally accessible. One agency noted in this connection:

My whole problem with the FDM program, especially west Indian but also Filipino women, is that they are happy to be a domestic for the rest of their lives. But the FDM pressures them to upgrade. They feel pressured not to be a domestic, and then they can't do anything else but go on welfare. 35

A second and contrasting response from the domestic placement agencies views the current predominance of migrant, and especially Third World, women in live-in care as unacceptable. These agencies perceive a need to improve the status and reputation of in-home care so that nannying will become a credible and respected profession for canadian women. This is the view, for example, of a leading spokesperson for the Canadian Coalition for In-Home Child and Domestic Care.

I feel we have to increase the status of nannying in Canada. You don't just need a physical body in the house if you need a nanny. A child orientation has to be a major concern. 36

This view is not necessarily characteristic of the coalition membership as a whole. It is, however, the perspective adopted by the International Nanny Association (INA). The INA is based in the United States, but has an international membership which includes members of the Canadian coalition for In-Home Child and Domestic care in canada. The INA defines itself as an

both programs are the requirements that the foreign domestic provide two years of live-in service, and the temporary resident status of the worker for those initial two years in Çanada.

35 Interview, December 12, 1991, A. Bakan with Agency "H"

36 Interview, September 16, 1991, A.Bakan with Marna Martin. 
organization committed to "maintaining high standards of professional conduct" in regard to the "professional development" of nannying in America and internationally.37 The corollary message to the INA's philosophy is that non-American, and non-American trained nannies are poor childcare providers. In this vein, INA publications warn parents to "Beware the Au Pair."

You may or may not have any idea what the au pair knows of American life. She may become terribly homesick and leave immediately. If she stays, the preemployment letters written in laboriously executed English may be the extent of her language comprehension. Chances are that the appliances common to American middle class households are foreign to her. If her language skills are marginal, she will certainly have difficulty reading the instructions.... It is very difficult for an American to assess the child care skills of a foreign au pair, much less her family or moral character. Even the au pair who has had extensive training in a child care related field may not be particularly skilful with your children yet there she is and you are stuck with her. 38

The racialized criteria therefore apply not only to the screening process of prospective in-home care givers, but also

37 "International Nanny Association: Commitment to Professional Excellence," adopted as part of the "Recommended Practices," INA 6th Annual Conference, Dallas Texas, June 2729. 1991. Observer's notes, A. Bakan

38" Deborah Davis, "Beware the Au Pair," n.d. In the US, there is a growing movement, of which the INA is a part, to provide professional certified training programs for nannies in college curricula. The INA has also been involved in lobbying to allow trained nannies with NNEB certificates from Britain to enter the US as skilled workers. Currently, these efforts have been denied. In Canada, Sheridan College offered such a program from September, 1973 to May,1989 (first titled the Canadian Nanny Program, and then the Family Care Assistant program). However, it was eventually cancelled due to an insufficient number of applicants. 
to an ascriptive set of criteria regarding "Canadian" and "American" family needs. The assumption of universality of a white middle class, English-speaking nuclear family precludes, for example, the large percentage of families in North America for whom English is not a first language, and whose children may not normally speak English at home. The overtly racialized discourse and practices, however, enter more directly in the recruitment and screening process assigned to the applicants. This brings us to a consideration of the construction of stereotypes which is central to the match making process.

Constructing the stereotypes: "The Island Girls" and "Your Filipinos"

Gatekeepers to citizenship serve to regulate the entry into and exit from nation-states and labor markets, as well as access to citizenship rights. All gatekeepers accomplish this work in part through the construction, articulation and reproduction of stereotypes about who is, or is not, an appropriate candidate for citizenship within a given nation-state. Such stereotypes are most often inscribed with discourses and somatic images that simultaneously assume certain types of racial, ethnic, gender, class, and sexual appropriateness. As defined by Barbara Bush, "A stereotype is a composite picture of an individual which, while reflecting an element of reality, distorts it.... It is flexible and [yet] can exhibit a massive durability, even in the face of historical change. "39

Racial stereotyping is endemic to the matching process which defines the parameters of the domestic placement industry. successful domestic placement agencies pride themselves in their ability to render a perfect "match" between client and applicant. In practice, this frequently means the ability to stereotype "appropriately." This is not, however, only a recent

39 Barbara Bush, slave women in Caribbean Societ (Kingston: Heinemann Publishers Caribbean, 1990), 12-13. 
characteristic of in-home care, nor is racial stereotyping unique to this particular form of gatekeeper. From the early 1900 s to the 1960s, white European domestics were favoured in Canadian policy, and were provided with less restrictive conditions for permanently residing in the country. These young women, primarily from England and Scotland, were recruited with an eye to a racially-identified "nation-building" project. The anticipation was that these women of "good stock" would become the wives of white Canadian men and the future mothers of white Canadian children. 40

In the early part of this period, the racially specific gender ideologies associated with the recruitment of white female domestic labor were supported by the historically dominant role of British imperialism in the western world. Similar domestic norms were characteristic in other parts of the empire. The availability of white European women for this type of work declined, however, as industrial expansion opened up other options for them. Moreover, as colonial policies dislocated millions of non-white women from agricultural subsistence production, another source of servant labor was brought in to replace European women. Male workers in the colonies were no less forced into poverty and unemployment, but domestic labor remained the domain of women workers. 41

British imperialism was not, however, the only global force behind the racialized and gendered processes of allocation into

40 See Abigail B. Bakan and Daiva K. Stasiulis, "Foreign Domestic Worker Policy in Canada and the Social Boundaries of Citizenship," ms., July 1992; Daiva Stasiulis and Glen Williams, "Mapping Racial Hierarchy in the Canadian Social Formation, 1860-1914: An Examination of Selected Federal Policy Debates," presented to the Annual General Meeting of the Canadian Political Science Association, Charlottetown, Prince Edward Island, Canada, June 1992; Devan (1989); Marilyn Barber, "Sunny Ontario for British Girls, 1900-30," in Jean Burnet (1990), and "The Women Ontario Welcomed: Immigrant Domestics for Ontario Homes, 1870-1930," Ontario History 3, vol. 72 (September 1980) : 148-172

4 Enloe (1990) provides a concise summary of this general pattern on an international and historical scale, 177-194. 
domestic work. Other colonial powers have continually produced and reproduced ideological models to support the exploitation of colonized women as paid domestic servants. For example, Belgian colonial policy in Africa after world war Two included the opening of foyers sociaux, training centres to teach African women the proper gender norms of the European nuclear family.42 Throughout colonial Africa, British, Dutch and French imperial policy included homecraft classes for women and young girls. In Latin America, Asia and the Caribbean, the legacy of centuries of imperialism has led to the continual creation of unemployed female workers who are recruited to perform domestic duties for the families of colonial settlers or the families of the indigenous urban elites. 43

The African slave trade, and the expansion of plantation societies in the Caribbean and the southern United States, were similarly central to this global process and were pivotal linkages between racism and the exploitation of female domestic

42 Nancy Rose Hunt, "Domesticity and Colonialism in Belgian Africa: Usumbura's Foyer Social, 1946-1960," Signs: Journal of women in Culture and Society5, 31: 447-474

43 See for example Deborah Gaitskell, "Housewives, Maids or Mothers: Some Contradictions of Domesticity for Christian Women in Johannesburg, 1903-39," Journal of African History 24, 2 (1983): 241-56 and "'Christian Compounds for Girls': Church Hostels for African Women in Johannesburg, 1907-1970," Journal of African Studies 6, 1 (1979): 44-69; Audrey wipper, "The Maendeleo ya Wanawake Movement in the colonial Period: The Canadian Connection, Mau Mau, Embroidery and Agriculture," Rural Africana 29 (Winter 1975-76) : 195-214; Margaret Strobel, "African Women: A Review," Signs: Journal of Worien in Culture and Society 8,1 (Autumn 1982): 109-31; Elizabeth Jelin, "Migration and Labor Force Participation of Latin American Women: The Domestic Servants in the Cities," Signs: Journal of women in Culture and society, 1 (Autumn 1977): 129-141; E. Chaney and M. Garcia Castro, (eds.), Muchachas No More: Household Workers in Latin America and the Caribbean (Philadelphia: Temple University Press, 1989): B. W. Higman, "Domestic Service in Jamaica Since 1750," in B. Higman (ed.), Trade, Government and Society in Caribbean History 1700-1920 (Kingston: Heinemann Educational Books Caribbean Itd., 1983); Patricia Mohammed, "Domestic Workers," in Pat Ellis (ed.), women of the Caribbean (London: Zed Books, 1985): 41-6 
labor. Black women, as slaves and servants, were commoditized as both the laborers and sexual objects of their white masters. Out of these conditions flourished the image of "Aunt Jemima", the Black "mammy" who was expected to care for the children of white ladies in the slave conditions of plantation America.44 slavery in the colonies coincided with slavery and domestic service in Britain. During the rule of Queen Ann, one advertisement is indicative of the conditions faced in the slave ports of Bristol. It offered a reward of a guinea for the return of "a Negro Maid, aged about 16 Years, much pitted with the small Pox, speaks English well, having a piece of her left Ear bit off by a Dog; She hath on a strip'd Stuff waistcoat and Petticoat. 145

This debased image of the Black domestic slave contrasts sharply with that of "Mary Poppins" the firm but loving white governess for white upper class children. Even during fin de siecle Britain, however, Mary Poppins was a caricature of only one segment of British nannies. College nanny training in Britain began in 1892 with the opening of the private Norland Institute at Notting $\mathrm{Hill}$ in Iondon. The purpose of the Institute was "to supply the public with ladies as nurses for young children." Today, the Norland Nursery Training College, now near Hungerford, is only one of three private colleges among some 200 mostly public college programs that offer the National Nursery Examination Board (NNEB) certificate in Britain.46 of

44 A thorough exploration of class relations in plantation America as they relate to racialized gender roles can be found in Elizabeth Fox-Genovese, Within the Plantation Household: Black and white Women in the old South(Chapel Hill: University of North Carolina Press, 1988). See also Sutherland (1981), who summarizes: "The southern mammy was the symbol of the perfect nursemaid and the model of faithful service throughout the nineteenth century." (142). Regarding the British Caribbean experience, see Bush, (1990). 45 Unidentified newspaper advertisement, cited in John Ashton, Social Life in the Reign of Queen Anne Taken from Original Sources (Chatto and Windus, 1882), I.81 by Peter Fryer (London: Pluto Press, 1984), 63

$46 \mathrm{~J}$. D. Brierley, R. H. Fryer, and E. Goldschmeid, A Future for Nursery Nursing: Report of the Panel of Inquiry Appointed by the National Nursery Examination Board(London: NNEB, 
the approximately 10,200 post-secondary students enroled in the program, the majority are "upper working class or lower middle class," and are unable to pay the high fees required by the private institutions. A considerable portion of NNEB students are also of racial and ethnic minorities.47 All of these students must follow the same basic curriculum of work and satisfy the same conditions for earning an NNEB diploma.48

In the nineteenth and twentieth centuries, various racialized and gendered images of domestic workers and caregivers have grown out of efforts to supply white, affluent families with domestics out of conditions of slavery, colonialism and an increasingly international market. One purpose of the ideological stereotyping has been to portray a fictive universality of the non-white, female "other" whose biological and "natural" make-up ascribes her to be inherently appropriate for private domestic service. Another has been to rationalize allocation of different groups of migrant women, by skin color and other invidious distinctions, into a racial/ethnic hierarchy within domestic work. 49

n.d. (e1980)), 7,22. This work puts the number of NNEB colleges at 146. The higher figure is for 1992. Interview, A. Bakan with Maureen Smith, Senior Assistant Director, NNEB, St. Albans, England, July 16, 1992

47 Interview, A. Bakan with Maureen Smith, July 16, 1992

48 The National Nursery Examination Board (NNEB), The Diploma and Preliminary Diploma in Nursery Nursing - Modular Scheme: An Overview, 1992 (St. Albans: NNEB, 1992). The NNEB is an intensive program of two years of full time study, involving health, educational and socio-cultural issues in the curriculum. Notably, the current syllabus includes training in "understanding of a child's developing awareness and experience of race, gender and disability, the possible outcomes of membership of any group open to discrimination and the need to avoid stereotyping." (NNEB, The Diploma $(1992), 12 f f)$.

49 In her study of Iive-in domestics in Metro Toronto, Rina cohen found that there was a tendency to prefer lighterskinned women for childcare and cooking and Black women for general housework. Rina Cohen, "The Work Conditions of Immigrant Women Live-in Domestics: Racism, Sexual Abuse and Invisibility," Resources for Feminist Research 16, 1 $(1987): 36-38$. 
In the US, one placement agency owner explained why so few nannies of color were active members of the International Nanny Association.

The INA attendance at this or other INA conferences is not representative of nannies in general in the United states. In my agency, we hold "Nanny get-togethers," and there the representation would be quite different. Here you are seeing the American nannies, and they generally do not work in the city but in suburban areas. The profile in the city would be a mix. They are 22 to 55 years old, some would be Black. Some would be the typical Black mammy, you know, who had raised ten kids of her own and was a grandmother by the time she was 45, with a big bosom, you know. Others would be puerto Rican. A mix. But all vould be resident aliens, that is have their green cards, but not all of them would be American citizens. 50

The notion of the "American nanny," who is neither Hispanic nor Black nor an immigrant, is reflective of the attempt to create a new stereotype distinct from the "others," though it is precisely these "others" that are in fact more reflective of empirical reality. In this agency owner's projected image, it is quite clear that the "Black mammy" and the "American nanny" are in counterposition to one another.51 The gatekeepers therefore

50 Interview, June 27, 1991, A. Bakan with Agency "J" 51 bell hooks explains the historic and contemporary image of the Black mammy as follows: "Her greatest virtue was of course her love for white folk whom she willingly and passively served. The mammy image was portrayed with affection by whites because it epitomized the ultimate sexist-racist vision of ideal black womanhood complete submission to the will of whites. In a sense whites created in the mammy figure a black woman who embodied solely those characteristics they as colonizers wished to exploit. They saw her as the embodiment of the passive nurturer, a mother figure who gave all without the expectation of return, who not only acknowledged her inferiority to whites but who loved them." (Ain't I a Woman: Black Women and Feminism(Boston: South End Press, 1981), 84-5). 
play a role not only in defining the racialized images appropriate to the non-citizen nanny, but also to the citizen nanny.

In Canada, the Live-in Caregiver Program and its antecedent, the Foreign Domestic Movement (FDM) link the tasks of the domestic placement agency with both external and internal stereotypical images. That is, the foreign domestic worker both in her home country and within canada is subject to a specific series of ascriptive characteristics within a totalizing stereotype. For the last decade, the largest single source region for live-in care in Canada through the LCP/FDM has been the Philippines, followed by Europe, the United Kingdom, and the English Caribbean (principally Jamaica, Trinidad and Barbados). Since the mid-1970s, however, among Third world source countries there has been a precipitous drop in the number of new entrants from the Caribbean and an inverse increase in those from the Philippines.

The reasons for this shift are difficult to determine, but it is clear, as will be demonstrated below, that unemployment, poverty and pressure to emigrate abroad from the Caribbean source countries have not declined. There is evidence to suggest tiat the shift was not entirely accidental, and that gatekeepers is: Canada played a significant role in nudging along this shift. A memorandum from Ranjit S. Hall, the 1974 Chief of Immigrant and Migrant Services, addresses the processing of temporary employment visas for domestics destined to arrive in Canada from Jamaica. It describes a situation whereby counsellors from Canada Manpower government employment centres were refraining

Another explanation is offered by an African American domestic placement agency owner in the US, as

follows: "Mammies do the same work as nannies, but they don't do it for pay. The idea of a 'mammy' goes back to slavery. when payment was simply the chance to not be in the fields picking cotton, to be allowed to live with the white family. Now we want live-in childcare, but we expect to be paid for that work every Friday." "Working with Families and Nannies of Different Colors and Cultures" Workshop, INA 6th Annual Conference, Dallas, Texas, June 29, 1991 
"from forwarding orders to Jamaica" and "this has caused a build up there."52 Moreover, the shift in primary Third World source countries from the Caribbean to the Philippines coincided with a decline in the role of government counsellors in arranging the "match" with prospective employers in Canada, and the emergent and stepped-up intervention of private employment agencies in recruitment and selection.53

Interviews with owners of placement agencies in Toronto, the major host city in Canada for foreign domestics, reveal a definite pattern of racial and ethnic stereotyping of domestic workers. Such stereotyping delineates sharply between domestics of Caribbean and Filipino origin. Regarding the image of the former, the passive and loving "mammy" has been replaced by an apparently widely accepted image that is variously aggressive, incompetent and cunningly criminal. Shifts such as these are difficult to measure. But the favour towards West Indian nannies seemed to have slipped in inverse proportion to a rise in militancy and organized resistance among live-in domestics to abusive conditions in canadian employment and immigration practices. This militancy arose at a time when Caribbean women predominated among Third world foreign domestic workers in Canada.

Symptomatic of this trend was the establishment in 1979 of a domestic workers' advocacy organization in Toronto, INTERCEDE. This organization was ultimately successful in winning the right to earn overtime pay, or time off in lieu of overtime pay, and also participated in a high profile campaign to reverse the deportation of "The seven Jamaican Mothers.1154 Militant

52 RG 76 83/84/349, Volume 150, File 5850-6-4-533 Part 6, Department of Manpower and Immigration. Memorandum to $W$. $K$. Bell, Director, Progran and Procedures, as cited in Daenzer (1991), 208, n.15.

53 See Daenzer (1991), 190-91.

54 See Ontario Task Force on Hours of Work and overtime (Arthur Donner, Chair), Working Times: The Report of the ontario Task Force on Hours of Work and Overtime(Government of Ontario, May 1987); Monica Townson, Domestic Workers and the Employment standards Act (report prepared for the ontario 
organizing for domestic workers' rights was not consistent with the historic "mammy" stereotype. Domestic placement agencies operating in the l990s are not necessarily aware of this history. However, as mediators of federal immigration policy at the level of the private Canadian home, they play a central role in transmitting and reproducing stereotyped images that accord, in distorted form, with such a history. Here is how one agency owner put the case:

I'm at the point now, where if I hear it's an island girl on my answering machine, I won't even interview. If you're from Jamaica, I won't interview you. I know this is discrimination, but I don't have time for this. Often at the end of a day, out of 20 messages on my answering machine, I'd say 18 are from the islands. I don't want them....Jamaican girls are just dumb. They are not qualified to be childcare workers. It's not their fault; they just don't have the education. They can take two hours to fill out a nanny application form. I'd love to get called up by Human Rights. If I were called in, I'd say to them: "Do you have children? Do you care about them? Would you leave your child with someone who was incapable of dialing 911?"55

As 'middle-women', the agencies also reflect the stereotyped images held by their clients. If an employer has had what she

Task Force on Hours of Work and Overtime) (Government of Ontario, september 1987); and, on other results of INTERCEDE's pressure regarding domestic workers' rights, see Daenzer (1991), 242-49. On the "Seven Jamaican Mothers" see Silvera (1989), "Introduction to the Second Edition," v-xi; Macklin (1992), 734-735; and Ronnie Leah and Gwen Morgan, "Immigrant Women Fight Back: The Case of the Seven Jamaican women, Resources for Feminist Research 7:3 (1979):. There were also other organizations involved in domestic workers' rights advocacy. See Mirjana Vukman-Tenebaum, "Organising Domestics in Ontario," and Rachel Epstein, "Domestic Workers Organizing The Experience in B.C.," Resources for Feminist Research 10, 2 (July 1981), 32-3 and 33-4

5sInterview, October 23, 1991, A. Bakan with Agency "E" 
perceives to be a bad experience with a live-in foreign domestic, a common tendency is to avoid repeating the problem by avoiding the racial or ethnic population of which the employee was a member. Because childcare and housework are expected to be natural and not learned or taught, drawing upon an alternative gene pool, rather than providing different instructions or seeking a different combination of acquired credentials, is seen as the best remedial approach. Moreover, racist stereotyping from the employers determines the actual job description for which the placement agent is hired to satisfy. As bluntly stated by one agency owner:

The employers are very prejudiced against the West Indian girls. 56

According to another agency owner:

It is much harder to place a west Indian than a Filipino. We say to our clients that you can't stereotype, that there are good and bad candidates in every race. We tell our employers, "Leave it up to us. Let us present you with the best candidate for the job." But we have a hard time placing west Indians in jobs. I know that that is discrimination, but they are looking for people to do jobs and to live as tenants. Sometimes the husband is really racist. or the employers will say that their children are afraid of someone who is of a different color. 57

Because the law regulating the recruitment of foreign domestics requires an offer of employment before entering the country, this pattern of discrimination becomes supported by restricted access to the Canadian labor market. Anecdotal evidence suggests that more prospective domestic workers from the Caribbean are being forced to enter Canada on visitors'

56 Interview, December 12, 1991, A. Bakan with Agency "H"

57Interview, November 6, 1991, A. Bakan with Agency "F" 
permits, refugee papers, or as illegal immigrants, creating a vicious cycle in the stereotyped image. Unless a work permit is granted, placing domestics with these immigration statuses is illegal, and the employee, employer and the placement agent could all be charged under current canadian immigration law with having committed criminal offences. The myth of the "Jamaican criminal" has recently been cultivated in a series of major news stories in the Canadian press, which reinforce the image of the illegal domestic trying to "scam" a job.58

There are not too many West Indian nannies these days. A lot of girls from st. Lucia, Barbados, and so forth, a lot of them are illegal. Chances are if she's from there, she's illegal, on a visitor's permit and not allowed to work. I can't deal with her then. 59

The negative stereotyping of West Indian "island girls" has not, however, generated a more realistic image of foreign domestic workers from the other major Third world source region, the Philippines. Agency owners tend to present a composite of passive and active traits among "your Filipinos."60 This image is notable for the contradictory manner in which passivity with the children is seen as a negative attribute, but a proactive relationship with the employer is not seen as a positive one. one agent's perspective in this connection is worth quoting at some length:

Most of my placements are from the Philippines, more than 50 percent, by far the highest percentage. Filipino nannies are very soft, they don't stimulate the children. They cannot control the children, it doesn't come naturally to

58 See Timothy Appleby, "Crime Story: The Jamaican Connection," in three parts, The Globe and Mail (July 10, 11 and 13,1992 )

59 Interview, october 15, 1991, A. Bakan with Agency "D" 60 Interview, May 21, 1991, A. Bakan and D. Stasiulis with Agency "I" 
them. Socially, the Filipino nanny comes from a culture where they are extremely respectful of elders, of authority, and they are trained not to offer their views too aggressively....Filipino nannies were always more giving, very professional in a sense. But now the shine is coming off the Filipino nanny.... I know this, because some clients have told me this. It doesn't apply to all the Filipinos. Generally, Filipinos are good with housework, but not always. You could always get a dud. 61

As Filipino domestics increasingly look to collective strategies to challenge exploitive conditions, domestic placement agencies are similarly altering their formerly positive perspectives.

A group that you can say come to work here just to get landed [i.e., obtain landed immigrant, or permanent, status] are the Filipinos. For them, what they are after is money, money, money. With other groups, some stay and some don't.... There is a surplus of Filipinos here who are being sponsored by legitimate offers. There is a surplus of bodies in this country. 62

In response to a question regarding the relative number of Filipino domestics her business places, another agency responded, "Too many.... But the Filipinos are smarter than the island girls." 63

61 Interview, October 15, 1991, A. Bakan with Agency "D" 62 Interview, September 26, 1991, A. Bakan with Agency "B. Landed immigrants generally have access to the same citizenship rights as full citizens with the exception of voting in elections, running as political candidates, or taking up jobs involving national security. Landed immigrants are eligible to become formal "citizens" following three years of residence in Canada.

63 Interview, october 23, 1991, A. Bakan with Agency "E" 
A Class Act: Gender, Race and the Market

Regardless of the personal views of the domestic placement agency owners, as small business managers operating in a highly competitive market, the structural pressures to accommodate racially and sexually oppressive ideologies are compelling. When the private household is transformed into a waged workplace, a class division takes place inside its walls. If the transaction is legal, the home literally becomes registered with the government as a small business, and the interests of the employee and the employer are delineated along class differentiated lines.

Despite the mediating and matching role of the private domestic placement agent, the agency's interests in the match are not those of a neutral arbiter. Rather, there are profound structural pressures to identify with the employer over the interests of the employed domestic worker. The objective class interests of the agency as a small business supported by a clientele of employing families tend to mould and alter any countervailing forces which compel identification with the domestic employee.

Even though placement agents are commonly of the same gender as the domestic workers they place, and occasionally of the same race, the class dynamic separating their interests has a more profound and determining impact. Agency owners are also commonly of the same gender as the women employers who generally manage the working environment of the hired domestics, and more often than not are likely to be white and professional. Many placement agency owners are sympathetic to some notion of feminism, broadly defined as a commitment to the advancement of women's rights and opportunities. Their work is largely about 
enabling working women with professional careers to advance unhindered by the burden of housework and childcare. 64

The options for the future that may be available for white professional women enjoying full citizenship rights in a developed capitalist state, however, are not the same as the options available to poor and unemployed migrant women of color whose citizenship rights are severely limited and restricted. Moreover, the employment of the latter as a domestic servant can and does operate as a privatized means to advance the social citizenship rights of her employer.65 An identification with "women's rights" in an abstract sense does not necessarily entail a challenge to the traditional sexual division of labor,

64 one example of this perspective was conveyed at the 1991 Annual conference of the International Nanny Association. The INA's invited keynote speaker was Sarah Weddington, the Attorney responsible for winning the famous Roe $v$. Wade decision that legalized the right of women to abortion under the US Constitution in 1972. Weddington was returning after a previous invitation to the INA five years earlier, and her videotaped speech was applauded with an accompanying standing ovation. The content of her speech was decidedly pro-women's rights. But it was also decidedly pro-us establishment.

Weddington spoke favorably of both the Carter administration of which she had been a part, and of the Reagan administration, and implicitly compared the tasks of women's leadership to a Gulf war missile. Sarah Weddington, Keynote Address, INA 6th Annual Conference, June 27, 1991, Dallas Texas, observers' notes, A. Bakan. For more on Weddington's views see her books, A Question of Choice (New York: Putnam/ Grosset, 1992); and The Legal Status of Homemakers in Texas (Washington: National Commission on the Observance of International Women's Year, 1977). See also, Elizabeth $W$. Fernea and Marilyn P. Duncan (eds.), Texas Women in Politics: A Project of Sarah weddington, Jane Hickle and Deanna Fitzgerald (Austin, Texas: Foundation for Women's Resources, 1977).

65 Daenzer (1991), notes the silence of women employers of domestic workers in Canada during the 1960s and 1970s, when the rights of foreign domestics were subject to increasing restrictions. "Cheaply-valued domestics and their work contributed to the accumulative potential of middle-class women. And the low cost of employing a domestic worker increased the potential of enhanced class affiliation for employers of domestics. There was status associated with having a maid. Affordability of domestics bred prestige." (194). 
with women responsible for the performance of domestic duties and private childcare in the home. In fact, in the example of the domestic placement industry, there is a decided ideological enforcement of that division of labor. 66

Regardless of the personal preferences of the agency owners, the market in which the industry operates is dependent upon the privatization of domestic work. Not all domestic care workers are women. However, with the growing demand for live-in childcare, there is a definite market-bias towards the placement of women in these jobs. Indeed, the vast majority an estimated 98 percent of foreign domestic workers in Canada are women.67 This is not the result of a lack of male applicants to these positions. The same conditions of poverty and unemployment that compel Third World women to leave everything behind and accept the most undesirable working conditions and wages available in North America also compel Third World men to seek the same means of escaping extreme poverty. Agencies indicate, however, that the job market in private childcare is not considered suitable for men. This affects the screening process of applicants from the outset. One agency put bluntly a case that is widely echoed, "I don't interview males, though I get a lot of calls. I can't place males." 68

There are two explanations offered for the inability to place males in in-home care. The first is that North American families are particularly nervous about the threat of male nanny abuse of children. One agent, who estimates that perhaps one

66 A perspective which defines "women's rights" in practice as referring only to the rights of middle class women is not, of course, unique to the example cited here. On this there is an extensive literature. In one such discussion, Fox-Genovese (1988) identifies how "Northeastern middle-class women's attitudes towards immigrant and other poor or laboring women... might not impress us as wholly sisterly." (62 ff) 67 Department of Employment and Immigration, Report from statistical Review of FDM Program, Persons Entering the Foreign Domestic Program by Year and Gender, 1982-198,9 and Arat-Koc (1989), 34 68 Interview, October 23, 1991, A. Bakan with Agency "E" 
percent of all the successful placements are male, suggested the following:

There are lots of male applicants who want to come to Canada to work as domestics. But people are usually more hesitant to hire men as opposed to female nannies. There are more male nannies in Europe. They call them "mannies. 169

Another placement agent offered a second explanation: that women were simply naturally better suited than men for child care work. This view reflects and perpetuates the broader gender stereotyping in the business itself.

I've placed two men since I've been in the business, one from Ireland, the other from Hong Kong. The Hong Kong boy was good, but one of the children, a baby he was looking after, got very ill, a brain tumour at six months. He couldn't cope with it. It's hard for the men if there's a sickness in the family. For women, females, normally their maternal instincts will kick in. Those instincts will get them through that. Men don't have these. 70

The sexist stereotyping of domestic labor extends beyond the specific task of childcare, however. Because the placement agents depend upon "selling their product" to the employer, they present a class-specific viev: of freeing women from the burden of domestic responsibilities. One agent developed the image of what making a successful placement could mean for the prospective woman client in detail:

You have something more than money, you have your peace of mind. You have a wife at home. I have many, many employers

69 Interview, October 15, 1991, A. Bakan with Agency "D" 70 Interview, May 21, 1991, A. Bakan and D. Stasiulis with Agency "I" 
who say to me, "what I need is a wife." Imagine coming home at the end of a workday, and all the stress is off. The kids are happy, the laundry is washed and folded, you can smell the chicken cooking in the oven. The girls don't want to stick around with you and your husband at the end of their work day, so you have all the time alone you want. They stay for half an hour, or an hour, and they communicate about the kids, and then they leave to their room and you are home with your kids. It gives you peace of mind and it gives you your equilibrium. There is no such thing as a superwoman. ${ }^{71}$

Because the industry is comprised largely of small businesses which require minimal capital investment or overhead, it is not uncommon for domestic placement agencies to have been started by former or current employers of in-home caregivers. The class identification between the agency and the employer, as professional working women who hire domestics, therefore has an instrumental component. One agent prided herself in helping to improve the reputation of the industry by helping former clients to establish their own agencies. Another agent decided to start a business of her own after having been "caught in a scam with an unscrupulous agency."

I knew what I wanted. I said, "I want a wife." I was often away on business. And I thought, I can do this, and I can do it clean, I can do it right. So I started the agency. I don't have any nannies any more, because I don't want to deal with the garbage. And I was actually a terrible employer. 72

71 Interview, October 1, 1991, A. Bakan with Agency "C"

72 Interview, October 23, 1991, A.Bakan with Agency "E." It should be noted that it was made clear in this interview that "the garbage" referred to those considered to be unqualified nannies, not unscupulous placement agents. 
Just as being of the same gender as the vast majority of in-home domestic workers does not mitigate against the gender bias of the placement agency industry, neither does it appear that ethnic and racial identification among women of color agency owners with domestic workers offsets the tendency towards racial stereotyping. While it is difficult to know what percentage of placement agency owners in Canada are people of color, among the high-profile public representatives of the business, the number is very small. However, maintaining a successful business that caters to employers tends to compel a racially biased business orientation, regardless of the color of the agency owner. The low status of paid domestic work, and the structural inequities and systemic racism that drive immigrant and visible minority women to accept such work, color-codes, as it were, the market of the industry. One agency owner who was herself an immigrant indicated some identification with the experiences of foreign domestics.

I understand what it's like living in one room with your whole family. It takes a lot of time to get established. 73

Nonetheless, the general perception of this same agency owner is that those foreign nannies who seek good quality working and living conditions, or wages above the legal minimum, hold unrealistic expectations.

I advise my nannies that they can get a good job these days, but they may have to compromise on the salary or the location. For example, they may have to take a job in the suburbs for minimum wage....For some of these girls, I think their expectations are much too high. The girls milk the system here for all it's worth. They are employed in nice homes, sometimes families that are very well to do. The girls want to have a really nice place to live in. 74

73 Interview, October 15, 1991, A. Bakan with Agency "D"

74 Ibid. 
Another agency owner whose business only places Filipino domestics, and who is of Filipino origin, was indistinguishable from other agencies in the racialized attitude displayed towards her applicants.

\begin{abstract}
We don't like to bring them directly from the Philippines. If they come directly here, you have to, well, baby-sit them. Even though they are the same merchandise, so to speak, they haven't blended yet. It's better if they have worked in Europe or Hong Kong or Singapore. 75
\end{abstract}

Though the placements of this business are all Filipino, the clients are overwhelmingly white canadians. The agency has developed a loyal clientele by providing Filipino domestics for white families who request them.

We ask our clients, what is their preference. There is no point in giving a Filipino unless they want one. We get no requests for West Indians. My clients will say, "please, don't send me soneone from the islands. Please give me a Filipino." And I say, "We have thick accents, you know." Although they may be comfortable in English, I don't think the English training in the Philippines is enough. 76

At their 1991 conference, the US-based International Nanny Association explicitly addressed issues of race and color in the placement agency industry. A workshop entitled "Working with Families and Nannies of Different Colors and Cultures" was led by two co-owners of a domestic placement agency. Both were

75 Interview, october 6, 1992, A. Bakan with Agency "K". It is, of course, formally illegal for any employment agency to bias its placement policies towards one specific applicant cohort on the basis of race, nationality or ethnicity. However, this agency is licensed in ontario and runs a highly successful business which is primarily dependent upon personal referrals for its clientele.

76 Ibid. 
African-American women, mothers of small children, and employers of full time live-in nannies. Introducing the workshop, one of the co-owners, referring to the previous year's INA conference, stated:

It seemed that last year nobody wanted to touch this type of workshop, that people were afraid to discuss it. We're not afraid of it; we're it. 77

With notable self-assurance, the agency owners presented the case for an open and "up front" approach to issues of both race and racism, and insisted that business objectives had to come first. The following advice to fellow agencies was included in the presentation that opened the workshop and is worth quoting at length:

We're not experts, and we won't tell you how to run your business. It has to work for you and your community.... We ask our nanny applicants if they have any cultural or racial preferences regarding where they want to work. Typically they say "no." But then we ask them: "Do you know how to take care of a six year old Black girl's hair? you know you can't just wash it and blow dry it.".. There are some areas, like South Boston, where you wouldn't place a Black nanny. Where could she walk that baby? I worked in Boston for one year as a bank teller. I couldn't believe what easy money this is, because no clients would ever come in my line.

But knowing this, don't lose your money. I won't close my business to lily white families just adjust to them and place a white nanny.... Like the nannies, we ask our families if they have a racial preference. They typically say no. Then we say, we have white, Black, Asian and Hispanic nannies. Then they consider, and say this and

77 "Working with Families and Nannies of Different Colors and Cultures" Workshop, INA 6th Annual Conference, Dallas, Texas, June 29, 1991. Observers' notes, A. Bakan. 
that. Not everyone agrees with being this up front. We had a Black woman agent in our office who quit because of this practice. 78

The class perspective of the agency owners is also reflected in their apparent widespread suspicion of domestic workers' advocacy organizations. In Toronto, INTERCEDE is one such organization that has aroused considerable concern among domestic placement agencies.

INTERCEDE is basically like a union, and they want to protect domestic workers' rights.... What they want to do is fine, but they don't do it the right way.... They'll tell you all kinds of horror stories, and you don't get the other side of the story. There have been employers' agencies and employers who want to help, but they'll shun them. INTERCEDE is mostly Filipino girls. But it's just the radicals who are behind it. They have workshops that are completely negative. They'll do chants and things they make up. It's really just like a union.79

Another agency shared this view, as follows:

INTERCEDE is almost like a union. It's very militant, and it's giving the Filipino nannies a bad name..... INTERCEDE will tell them: "Don't work for one minute after 6:00 pm. If you work one minute more you are being abused. "180

The Canadian Coalition for In-Home Child and Domestic Care, in which placement agency owners are strongly represented, has explicitly challenged INTERCEDE's argument that compulsory livein work is exploitive and should be eliminated from the foreign

78 Ibid.

79 Interview, November 6, 1991, A. Bakan with Agency "F" 80 Interview, October 15, 1991, A. Bakan with Agency "D" 
domestic worker legislation.81 In January 1992, legislative changes to the foreign domestic program confirmed the two year compulsory live-in requirement. Further, the revised law raised the criteria for eligibility from a recommended one year of related experience, to a required Canadian Grade 12 equivalency as well as six months of supervised training. INTERCEDE joined domestic advocacy groups from across the country in protesting the changed regulations. The organizations representing the interests of domestic workers argued that the new policy would discriminate against women from Third World countries where such educational opportunities are more limited than in Europe and where training programs in care-giving occupations do not exist. 82

In contrast to the protests by domestic advocacy groups, the canadian coalition welcomed the increased restrictions, particularly the Grade 12 equivalency requirement, maintaining that it would improve the quality of in-home childcare.83 In

81 See Carmencita Hernandez, "Organizing Domestic Workers," in R. Argue, C. Gannage and D.W. Iivingstone (eds.), Working People and Hard Times (Toronto: Garamond, 1987), 297-300; and Patricia Henry, President, Canadian Coalition for In-home Child and Domestic Care, Workshop on "International

Perspectives," INA 6th Ánnual Conference, Dallas, Texas, June 27, 1991. Observer's notes by A. Bakan.

82 ' Canadian Advisory Council on the Status of Women, Meeting with domestic worker groups and government representatives to discuss the new regulations of the foreign domestic worker policy (FDM/LCP), February 1, 1992, Ottawa, Observer's notes by D. Stasiulis. A sample survey conducted among 213 of INTERCEDE's membership revealed that only 19 percent of those currently working as live-in domestics in Canada, who entered under the previous regulations, would qualify if they were compelied to adhere to the new ICP stipulations. Foreign domestics currently in Canada who were admitted under the earlier regulations are not subject to the 1992

qualifications. Domestics' Cross-Cultural News, Monthly Newsletter of the Toronto Organization for Domestic Workers' Rights (INTERCEDE), September, 1992, 1-2.

83 Wendy Doyle, minutes for the Canadian coalition for InHome Child and Domestic Care, Summary of Commons standing Committee on Labour, Employment and Immigration Hearing, ottawa, February 26, 1992 ; and Canadian Coalition for In-Home Child and Domestic Care Newsletter February, 1992, 1; and 
adopting this position, the coalition placed itself on the other side not only of domestic rights advocates, but also the government's own appointed Standing committee on Labor, Employment and Immigration.84 The model for the new training entrance criteria, which critics of the new law maintain is being implicitly favoured, is the British nanny training college. Domestic workers entering Canada with an NNEB diploma normaliy do not do housework, and receive higher wages for providing in-home childcare. Upon learning of the revised Canadian legislation, however, the Assistant Director of the NNEB in Britain was convinced that six months of training was inadequate to meet the needs of quality nanny training. She further questioned the qualifications of Canadian visa officers, untrained in professional childcare, to assess the quality and staridards of the training received. 85

While the recent policy changes expressed in the live-In Caregiver Program are consistent with recommendations made by the Canadian Coalition for In-Home Child and Domestic Care, it cannot be concluded that all agencies in Canada were represented in this policy decision.86 Indeed, the large pool of potential

Canadian Coalition for In-Home Child and Domestic Care, "News Release," February 14, 1992

84 Sub-Committee on Immigration, standing Committee on Labour, Employment and Immigration, "Report to the House," (Canada: House of Commons, July 1992). The editors of a major national daily also disapproved of the restrictions. see "A Blot on Canada" (editorial), Toronto Star, August 11, 1992 85 Interview, A.Bakan with Maureen Smith, July 16, 1992. 86 Significantly, at the hearings of the standing committee on Labour, Employment and Immigration into changes to the Foreign Domestic Program, a spokesperson for the British Columbia Nanny Agencies Alliance, expressed her concern that "the present schools, almost exclusively based in Caucasian countries [might not] realistically [be able to] provide the number of nannies and the variety of skills required by Canadian families." This witness also argued that "on-the-job experience, rather than formal training, is the most important qualification" in childcare. Iinda Rogers, "Minutes of Proceedings and Evidence of the Sub-Committee on Immigration of the Standing Committee on Labour, Employment and Immigration," House of Commons, Issue No.2, April 7, 1992, 6-7. 
applicants under the LCP who do not qualify under the new regulations will be under greater pressure to by-pass official channels and official agencies. Migrant women on visitor's visas, or with no official immigration status, represent a loss of business revenue for official, registered agencies.

The perspective of the canadian coalition on increased training requirements for foreign domestics is, however, consistent with the class interests of placement agencies, insofar as their role in screening and selecting applicants could potentially be enhanced as a result of a more restrictive policy. For employers concerned to meet the new conditions, hiring a domestic through a professional domestic placement agent would ensure that the more stringent requirements are met. Further, the more general commitment on the part of the canadian Coalition for In-Home Child and Domestic Care to the compulsory live-in requirement is clearly consonant with the general interests of the private domestic placement industry. It is primarily the live-in condition that makes the work unattractive to non-immigrant labor; and it is also this condition which renders the applicants, as non-citizens, dependent on private agents to secure an offer of employment as a condition for entry into the country.87 Gatekeepers, in other words, are only necessary if the gates are difficult to open.

Poverty, underdevelopment and Domestic Workers

The process of recruitment of migrant women workers to perform paid domestic labor in developed capitalist states is structurally linked to the uneven pattern of international economic development, international migration patterns and

87 Workers who enter Canada on the FDM/ICP therefore bear characteristics common to indentured labour, and are compelled to participate in a separate, and unfree, labour market. On the dependence of capitalism historically and today on various forms of unfree labour, see Robert Miles, Capitalism and Unfree Labour: Anomaly or Necessity?(Iondon: Tavistock, 1987) 
regulations, as well as racially and ethnically specific ideological discourses. In post-colonial conditions, the legacy of imperialism has combined with modern conditions of indebtedness to generate large pools of female migrant labor in some Third World states to fill the demand in the domestic care industry of industrially advanced states.

Thus it is the historic policies and practices of First World countries, and the international organizations these countries dominate, that have served to exacerbate the conditions of poverty that migrant women hope to escape. structural adjustment policies, advocated by the International Monetary Fund (IMF) and the world Bank in particular, demand government cuts in social service budgets and public sector employment, econoric controls which favour the export of commodities over local market expansion, and tax incentives to transnational corporations.88 one result is increased pressure to migrate in search of employment. As opportunities for migration are directly tied to occupational demand in the First World, the gendered and racialized ghettoization of the labor markets of prospective countries of destination limits, and moulds the "supply" of prospective applicants. Those who wish to migrate, can legally do so only if they can prove that they are specifically suited to meet the employment profiles in demand: enter the Third world female migrant domestic. The Canadian government's policy of compulsory temporary residence status for domestic service "established a class of people good enough to do their dirty work, but not good enough to be permanent residents. 189

88 Cheryl Payer, The Debt Trap: the International Monetary Fund and the Third World (New York: Monthly Review, 1974), 42. See also Raul I. Madrid, Over-Exposed: US Banks Confront the Third World Debt Crisis (Boulder: Westview Press, 1992); and, on the relationship between imperialism and the structural construction of migrant labor on a world scale, see Robin Cohen, The New Helots: Migrants and the International Division of Labour (Hants, UK: Gower, 1987). 89 Martin and Segrave (1985), 121 
The existence of large numbers of Third world workers, highly motivated to achieve secure employment for themselves and their families, has mitigated against the operation of a pure market model of supply and demand with reference to domestic labor. 90 In conditions of a chronic labour shortage, classical economics would predict an increase in wages and the quality of working conditions in order to attract laborers. However, domestic labor has proven to be remarkably "immune to the regulatory infection"191 of the market. This is primarily because of the restrictive conditions of employment to which noncitizens in search of gaining the anticipated security of citizenship are prone. In the US, the notion of "housekeeping for the Green Card," is paralleled in the canadian context by the practice of "doing domestic to get landed."92 Moreover, racial and gendered barriers to labor mobility also restrict the alternative employment options of domestic workers, even once formal citizenship is obtained.93 Migration and paid domestic service are thus elements of a global process of linkages, in which gendered and racialized ideologies play a significant part. 94

90 Ibid., 95

91 The phrase, taken from a somewhat different context, belongs to Phyllis Palmer. See "Housewife and Household Worker: Employer-Employee Relationships in the Home, 1928$1941 "$ in Groneman and Norton (1987), 180.

92 see Colen in Colen and Sanjek (1990) and Macklin (1992). 93 palmer points out, for example, that Black southern women who had migrated north in the 1930 s to work as domestics found, unlike earlier generations of Euro-American immigrants, that alternative sources of employment were not open to them (Palmer, 1989, 67ff.) In Canada, according to the federal government, domestic workers who have obtained permanent resident status after completing the required two years of live-in service on temporary employment visas, continue to find employment in the most poorly remunerated jobs. This argument was used to support increased educational requirements for foreign domestics to be eligible to perform in-home domestic service. See Macklin (1992), 757-760. 940 n the specific implications of gender to the international division of labor and the global process of capital accumulation, see Kathryn Ward (ed.), Women Workers and Global Restructuring (Ithaca: ILR Press, Cornell, 1990); 
The conditions of underdevelopment within the Philippines and the caribbean are central to the historic role of these regions as the major Third world source areas for the recruitment of foreign domestics in Canada. How Canadian domestic worker policy has been constructed to take advantage of these conditions, and has adapted its regulations accordingly, is critical to situating the gatekeeping function of the domestic placement industry in a global context.

The Caribbean region as a whole is heterogeneous, incorporating a wide variety of nations and influenced by a complex and variable set of external and internal economic, social and political factors. In general, however, until the nineteenth century internal migration was negligible, and external migration involved only a fraction of the population. Those who did migrate were usually of middle or upper class background, who were able to advance their prospects by obtaining permanent residence in Europe or North America.95

Swasti Mitter, Common Fate, Common Bond: Women in the Global Economy (London: Pluto Press, 1986); and Thanh-Dam Truong, Sex, Money and Morality: Prostitution and Tourism in South East Asia (London: Zed Books, 1990).

95 Following British conquest in the mid-17th century, the Caribbean was exploited as a region rich in land and capitalgenerating plantation agricultural conditions. In contrast, it was an area short in the supply of labor, particularly following the near-genocide suffered by the indigenous Amerindian population. After the early failure of a movement favoring white European indentured labor, the African slave trade soared and fuelled the profits of the colonial planters, primarily through the export of sugar and related products. With emancipation of the slaves in 1838 , an extensive peasantry emerged as freed slaves turned to private land cultivation and resisted field labor in protest to the legacy of slavery. Women played a central role in agricultural marketing, first during the plantation period for the sale of slave-grown produce, and then after emancipation. While other employment options have opened for women, this tradition has continued until the present time.See Eric Williams, Capitalism and Slavery (Chapel Hill: University of North Carolina Press,1944), which, despite volumes of contemporary debate, remains the best single concise historical source on this period for the Caribbean region. See also Janet Henshall Momsen, "Gender Roles in Caribbean Agricultural Labour," in Malcolm Cross and Gad 
During the 1960s and 1970s, this pattern started to change, with large numbers of West Indians seeking migration abroad. Most of the major studies of Caribbean migration for this period maintain that the increase was not necessarily a response to unemployment, but to increased opportunities for well-educated, relatively high status professionals.96 This is not, however, because unemployment did not exist. The British West Indies have seen chronic rates of unemployment between 20 and 30 percent of the work force. However, restrictive immigration laws in some of the most favored destination countries ensured that only the most skilled were permitted to enter.97

The 1960-1970s saw an increase in emigration outlets for Caribbean workers at the same time as political independence was negotiated with the British imperial state.98 Newly independent Caribbean governments hoped to offset chronic unemployment and secure sources of foreign currency in the form of remittances by encouraging migration abroad. By 1973, Jamaica, the largest of the British Caribbean nations with a population of about 2 million, registered more than one-half million citizens living off the island.99

Hueman (eds.), Labour in the Caribbean (London: Macmillan Caribbean, 1988): 141-158; Lil Despradel, "Internal Migration of Rural Women in the Caribbean and its Effects on Their Status," in UNESCO, Women on the Move: Contemporary Changes in Family and Society (1984): 93-109; and Abigail B. Bakan, Ideology and Class Conflict in Jamaica: the Politics of Rebellion (Montreal: McGill-Queen's University Press, 1990): 18-67.

96 see for example C. Peach, West Indian Migration to

Britain: A Social Geography (London: Oxford University Press, 1968)

97 See for example, Vic Satzewich, "Racism and Canadian Immigration Policy: The Government's View of Caribbean Migration, 1962-66," Canadian Ethnic Studies XXI, 1 $(1989): 77-97$.

$\$ \overline{8}$ For an insightful account of this process, focussing on the Jamaican experience, see Trevor Munroe, The Politics of Constitutional Decolonization, 1944-62 (Jamaica: Institute of Social and Economic Research, 1972).

99 European Economic Commission (1973) as cited in Despradel $(1984), 97$. 
Remittances are now a critical component for family survival in the region. Estimates of the value of remittances to the British West Indies are difficult to verify, given the variations among the islands and poor statistical records. One study provides a 1978 estimate of US\$23 billion, equivalent to roughly 10 percent of the countries' merchandise exports; a 1982 study suggests that remittances were the principal source of hard currency in several of the small islands in the region. 100

Evidence suggests that the early years of this emigration wave favoured the exodus of male workers. This coincided with the internal migration of female workers from the rural areas into the cities, particularly to work as domestic servants for private homes and in the burgeoning tourist and hotel industries.101 This pattern reinforced another: the historically large proportion of households headed by sole-support mothers. According to Momsen, though the proportion of female household heads varies greatly across the region, in general "[w]omen have had to accept responsibility for the financial support of their chilaren since emancipation because of both male migration and male economic marginality."l02 In 1970, the commonwealth

100 The first figure is drawn from Gurushi Swamy, "International Migrant Workers' Remittances: Issues and Prospects," World Bank Working Papers, no. 481 (Washington DC: World Bank, 1981); the second is from Hymie Rubenstein, "The Impact of Remittances in the Rural English Speaking Caribbean," in Return Migration and Remittances: Developing a Caribbean Perspective RILES Occasional Paper, no. 3, eds. William F. Stinner, Klaus de Albuquerque and Roy S. BryceLaporte (Washington DC: Research Institute and Ethnic studies, 1982). For a discussion of remittances to the region in general, and a review of the literature, see, wilbert 0. Bascom, "Remittance Inflows and Economic Development in Selected Anglophone Caribbean Countries," in Sergio DiazBriquets and Sidney Weintraub, (eds.) Migration, Remittances and Small Business Development: Mexico and Caribbean Basin Countries (Boulder: hestview Press, 1991): 71-99 IOI Desprodel (1984), 101; Momsen (1988), 151; Housewives Association of Trinidad and Tobago, Report on Employment status of Household workers in Trinidad(Port of Spain: HATT, March 1975)

102 Momsen (1988), 147 
Caribbean recorded 35 percent of all households headed by women; a 1986 study confirmed this figure, finding a ratio of one in three households to be under female headship.103 This factor, and the decline of agriculture as a source of profitable employment, compelled women to seek new sectors of work.104 Domestic labor in Canada was one such avenue.

Prior to 1962, Canada had an explicitly racist governmental policy restricting West Indian immigration to Canada. In1958, the Director of the Immigration Branch of the Department of Citizenship wrote:

[I]t is not by accident that coloured British subjects other than negligible numbers from the United Kingdom are excluded from Canada... They do not assimilate readily and pretty much vegetate to a low standard of living. Despite what has been said to the contrary, many cannot adapt themselves to our climatic conditions.105

In 1955, a limited number of West Indian women workers were permitted to enter canada on condition that they remain in domestic service with a contractually designated employer for one year: after this time they were permitted to obtain other employment. This policy was discriminatory. Unlike domestic workers from Europe, the west Indian workers received no government assistance in the cost of passage. Moreover, although permanent resident status was obtained upon arrival, Caribbean domestics were subject to special conditions of virtual

103 Cited in Ibid, 147 ; and Dorian Powell, "Caribbean women and their Response to Familial Experiences, "Social and Economic Studies 35, no.2 (1986): 83-127

104 By 1970, women's paid participation rate in the caribbean labour force overall had been superseded by work in the expanding service sector, largely fuelled by tourism and the hotel industry.

105 Cited in Satzewich (1989), 77 
indenture and the threat of deportation. Such restrictions did not apply to domestics from European source countries.106

Between 1973 and 1981, West Indian women workers were admitted as domestic workers on temporary employment visas. others entered as skilled workers, particularly in nursing when there were periodic labor shortages, or as sponsored relatives. The numbers as a whole, however, remain small and have been declining relative to other source countries. Between 1973 and 1978, of all those who obtained permanent, or landed, status in Canada, those from all caribbean source countries totalled only 10 percent; by 1980, that figure was 6 percent.107 one of the most rapidly increasing alternative source regions of immigration to canada overall, as well as in the migration of foreign domestics, is the Philippines. Thus, in the year from July of 1975 to June of $1976,44.8$ percent of all entrants to

106 The policy was implemented on a limited quota basis, with 100 Caribbean women admitted in the first year, and subsequent increases up to 280 per year. The plan was explicitly enacted, and then extended into the 1960s, to assuage the demands of Caribbean governments. For its part, the canadian government expressed explicit concern that upon achieving permanent status, sponsored relatives from the Caribbean would enter Canada and alter the racial complexion of Canadian society. However, Canada's economic interests in the English Caribbean, ranking third in the world after the United States and Britain, compelled concern that some accommodation to the region's political leaders on the immigration front were in order. See Satzewich(1989) and Daenzer (1991), 127-32 and 143-71 on the rise and fall of the West Indian Domestic Scheme; see also, Calliste, (1989): and Frances Henry, "The West Indian Domestic Scheme in Canada," Social and Economic Studies 17, no.1 (1968). On Canada's historic economic interests in the region, see Brian Douglas Tennyson (ed.) Canadian-Caribbean Relations: Aspects of a Relationship (sydney, Nova Scotia: Centre for International Studies, 1990); Robert Chodos, The Caribbean Connection (Toronto: James Lorimer, 1977); and Abigail B. Bakan, David Cox and colin Leys (eds.), Imperial Power and Regional Response: The Caribbean Basin Initiative(Wilfrid Laurier University Press, 1993).

107 The largest single source country was Jamaica, followed by Guyana, Haiti and Trinidad. Anthony Richmond for statistics Canada, Current Demographic Analysis: Caribbean Immigrants (Ottawa: Minister of Supply and Services, 1989),3 
Canada on temporary employment visas assigned to in-home domestic work were from the Caribbean, and only 0.3 percent were from all countries in Asia; by 1990, only 5 percent of FDM entrants were from the Caribbean, while over 58 percent were from the Philippines.108

In 1990, over 58 percent of the 11,000 new entrants to the Foreign Domestic Movement program in Canada were from the Philippines, compared with just under 25 per cent in 1982.109 Canada, however, is only one destination country for Filipino migrants. During that same eight-year span, the total number of Filipino processed contract workers had almost doubled.110 In 1990, the estimated size of the total Filipino workforce abroad, comprising both temporary contract migrants and those who have settled permanently abroad, was about 1.8 million.111 while in the 1980s, over three-quarters of Filipino overseas workers were males, the 1980 s witnessed an increasing exodus of female

108 After 1973 and prior to 1981, live-in domestic workers arrived on temporary employment visas with no special provision for the attainment of permanent resident status. Task Force on Immigration Practices and Procedures, Domestic Workers on Employment Authorizations (Ottawa: Office of the Minister, Employment and Immigration, April 1981), 49; Shiela McLeod Arnopoulous, Problems of Immigrant women in the Canadian Labour Force (January, 1979):61; "Statistical Profiles" (November 1990); Task Force on Immigration Practices and Procedures, Domestic Workers on Employment Authorizations, (Government of Canada, Office of the Minister of Employment and Immigration, April, 1981), 48-50; and "Foreign Domestic Workers in Canada - Where Do They Come From? How Has that Changed Over Time? "The Moment 2, vol.5 $(1991), 5$

109 Strategic Planning and Research Directorate, Employment and Immigration Canada, "Statistical Profiles," Table 2, 3 . 110 In 1982, the number of processed contract workers from the Philippines was 314,264, compared with 598,769 in 1990 . Moreover, the number of processed Filipino contract workers increased twenty-fold over a 16 year period, from just over 36,000 in 1975 to almost 700,000 in 1991. See Benjamin $v$. Carino, "Migrant workers from the Philippines," in G.

Batistella and A. Paganoni (eds.), Philippine Labor

Migration: Impact and Policy (Quezon City: Scalabrini Migration Center, 1992), 7,6.

111 Manolo I. Abella, "International Migration and

Development," in Batistella and Paganoni (1992), 27. 
migrant labor. This was in part a response to high levels of demand for nurses, domestic workers, and other types of service workers in Asia, the Middle East, Europe and North America.112

The unprecedented rise of Filipino emigration reflects both the growing internationalization of labor markets and the persistence of underdevelopment in the philippine economy.113 A number of structural factors linked to underdevelopment have triggered the large volume of labor flows from the country. These include the increasing scarcity of land, urban growth without sufficient expansion in urban employment to meet the supply of dislocated rural workers, and general poor performance of the economy. It is beyond the scope of this discussion to account for why the Philippines, unlike South Korea and Taiwan, with whom it shares similar characteristics, did not become a Newly Industrializing Country. Angeles' account, however, is persuasive, suggesting that the role of the state, burdened by the presence of a strong landlord class, has served to block the enactment of progressive land reform and the emergence of a strong indigenous entrepreneurial class.114 Moreover, critical development problems have been exacerbated by political instability. 115

Since 1974, with the formulation of the Philippine Labor Code,116 the Philippines Government has vigorously pursued

112 Carino (1992), 13.

113 The emergence of massive overseas employment of Filipinos coincided with the opening of the Middle East labour market. Maruja M.B. Asis, "The Overseas Employment Program Policy," in Batistella and Paganoni (1992), 69 .

114 Leonora Angeles, "Why the Philippines Did Not Become a Newly Industrializing Country," Kasarinlan, 7, 2 \& 3 $(1991 / 92), 91$.

115 For example, in 1984, following the assassination of Senator Benigno Aquino, leader of the opposition to the Marcos regime, some 86,000 workers were laid off by various corporations, and more than 50 per cent of families were living below the officially defined poverty threshold. Carino $(1992), 18$.

116 The signing into law of the May 1974 Philippines Labor Code "signalled earnest government involvement with overseas employment." The code provided for the creation of the 
overseas employment as a means of alleviating chronic unemployment and balance of payments problems.117 overseas employment has also been pursued by individuals and households as a means of improving economic stability and opportunities for Filipino families. According to data from the Philippine overseas Employment Administration, the country recorded the highest share of overseas land-based contract workers in the world for the period between 1984 and 1988.118 Further, a 1988 household income and expenditures survey revealed that fully 15.5 percent of families in the Philippines receive income from abroad contributing about 30 percent of their total incomes.119 one common family strategy is to subsidize the higher education

Overseas Employment Development Board (OEDB) to undertake a systematic program for the overseas employment of land-based workers, banned direct hiring, and made mandatory remittance of overseas workers' earnings. While the 1974 Code was intended to block out participation of the private sector in recruitment and placement, these tasks proved too onerous for the government to handle. Thus, in 1978, the government relegated to the private sector control over recruitment and placement of Filipino workers. Asis (1972), 71-72.

117 Economists acknowledge the substantial contribution of overseas migrants' remittances in offsetting the oil bill and improving the balance of payments, especially during the mid1980s, a period marked by massive foreign exchange problems and foreign capital flight. However, they differ in their assessments of the impact of migration on economic development in the Philippines. The most persuasive accounts conclude that overseas employment is only palliative in character, and that more lasting solutions to the country's critical development problems must address deeper structural factors. For further discussion of the impact of overseas employment on development in the Philippines, see Manolo Abella (1992); Noel Vasquez, "Economic and Social Impact of Labor Migration," in Batistella and Paganoni (1992), 39-67; Graziano Battistella, "Migration Opportunity or Loss?" in Batistella and Paganoni (1992), 113-134; Carino (1992), 19 ; and Vasquez (1992), 4T. 118 Ruby Palma-Beltran, "Filipino Women Domestic Helpers Overseas: Profile and Implications for Policy," Asian Migrant, 4:2 (April-June, 1991), 46. These figures are considered to be conservative, as they do not incorporate those who depart as tourists and are therefore not registered as official overseas workers. Macklin (1992), $695 \mathrm{n} .66$. II9 Abella (1992), 30 . 
of one family member who is then sent abroad to earn wages that are comparatively much higher than in the Philippines.

Indeed, Filipino migrant workers tend to have higher than average education. According to a 1980 study, over 50 percent of Filipino migrant workers surveyed had completed some college education, in comparison with only 12.5 percent of the Philippine labor force.120 In the context of a 40 percent unemployment rate among nurses in the philippines, nursing degrees are deliberately acquired as passports to work abroad, and thereby increase family living standards. What is calculated less frequently than the economic impact of overseas employment, both for the individual migrant worker and for the Philippine economy, are the social consequences of long-term separation of family members entailed in contract migration.121

In sum, it is thus not fundamentally the gatekeepers who produce the pool of migrant female labor for the domestic placement industry, but poverty and underdevelopment. But gatekeeping mechanisms do determine the terms and conditions of access into developed states as a means of attempting to escape extreme poverty. Citizenship practices internal to advanced states have favored the expansion of citizenship rights in a direction away from the performance of paid domestic service.122

120 Carino (1992), 13-14.

121 See Vazquez (1992), 60-62 for a discussion of the impact of overseas migration on migrants' families and communities. 122 In the United States, by the end of World war one, the number of white women in domestic service had declined dramatically, while Black women, who had worked in the homes of white women in the south, began migrating to northern cities. However, even these women preferred to live-out and to maintain some independence from their employers for at least part of the day. Allyson Sherman Grossman, "Women in Domestic Work: Yesterday and Today," Monthly Labor Review August (1980): 17-21; Bettina Aptheker, "Domestic Labor: Patterns in Black and White," in Woman's Legacy: Essays on Race, Sex and Class (Amherst: University of Massachusetts Press, 1982), 111-28; see also Palmer, Clark-Lewis and Ruiz in Groneman and Norton (1987) and Palmer (1989). 
Conclusion: Paid Household Labor, Gatekeepers and Citizenship

The low social status and remuneration, and the harsh working conditions of household work, have meant that advanced states have long drawn upon reserve pools of female labor from abroad to fill the continuing need for domestic workers. Within any given First world state, and within any given historical era, certain nationalities or ethnic groups have tended to predominate among foreign domestics. As one observer put the case, "household service drew the despised race to the despised calling."l23 The "common sense" explanations for such shifts tend to focus on characteristics of the respective racial/ethnic groups of women themselves, and the "fit" of these characteristics with the needs of employing families. While there are many factors accounting for the shifts in racial/ethnic profiles of migrant domestic workers, it is clear that the active intervention of several types of agents, or gatekeepers, is necessary to accomplish such shifts.

In. the process by which Third World migrant women become Iive-in domestic workers for families in First world states, the importance of the private domestic placement industry in rendering the "match" is elevated. The gatekeeping function involves a continuing process of locking and unlocking doors in a complex labyrinth which is dependent upon a global system of uneven state relationships. The dependency of the client on an individual placement agent is crucial to the success of the business. The dependency of the applicant on the same individual placement agent is similarly necessary to complete the transaction. The commodification of migrant women workers, the

123 The context of this statement is the increasing numbers of African-American women migrating from the rural southern Us to the urban north. Isabel Eaton, "Special Report on Negro Domestic Service," in WEB DuBois, The Philadephia Negro (New York: 1899), cited in Clark-Lewis (1987), 197 . 
transportation of "the merchandise"l24 as one agent cited above has termed it, is reflective of the class interests of the agency owners that predominate in this market-sensitive industry.

Domestic placement agencies draw readily from an arsenal of racially and ethnically specific images of women to-recruit certain groups of women for live-in care, and bar or restrict the entry of others. The genealogy of each specific racialized, gendered discourse is complex and multi-faceted. While relatively durable, each image can be altered under conditions which produce behavior that clashes with the image for instance, when the "shine comes off" one ethnic group of nannies who challenge the servile and indentured condition of the foreign domestic worker program. Patricia Daenzer's important account of Canadian foreign domestic worker policy between 1940 and 1990 points out how a secular decline in one of the most important citizenship rights namely the right to stay in the country occurred in proportion to the rise in the foreign domestic movement of women of color.125 In other words, the citizenship rights of foreign domestics diminished just as the bulk of new domestics diverged from the white, Eurocentric image of the "legitimate canadian." The apparently anomalous decline in citizenship rights for migrant domestic workers which took place in a climate of liberal welfare legislation and the broadening of legislated rights in the 1982 Charter of Rights and Freedoms, is in fact consistent with a long history of racist ("white Canada") immigration policies.

The structure of privatized live-in domestic service within the family unit imposes an inherent inequality between the citizen/employer/landlord on one side, and the noncitizen/employee/tenant on the other. The distance between the citizen and non-citizen, as these concepts are employed here, is not merely a legal category of official citizenship status.

124 Interview, October 6, 1992, A. Bakan with Agency " $K$ "

125 Daenzer (1992). 
Rather, this distance reflects a generalized spectrum of unequal relations perpetuated in the practices and ideologies of state and civil society.126 what is unique in the condition of livein domestic service of immigrant women, however, is the stark exposure of the "asymmetrical social relations of household work."127 As colen puts it:

Assigned to women as an extension of childbearing capacity, household work is naturalized, trivialized, and considered unskilled. It is further devalued as it passes across class, race, ethnic or migration lines from women who choose not to do it to other women who perform it in employers' households. 128

One of the key features governing relations of contemporary live-in domestic work is the unequal citizenship statuses between usually white, female professional employers, and predominantly migrant Third World female employees. Racialized and gendered ideologies cloak and mystify the unequal citizenship gates that are institutionalized within such programs as the ICP, and whose hinges are oiled by the work of gatekeepers. They conceal the fact that the foreign domestic program offers only a zero-sum game of citizenship, whereby certain gains for one group of women professional and most often white are granted by the state at the expense of another migrant women of color.

The race and class-specific character of ideologies and images of femininity, domesticity, and female sexuality has been emphasized in the growth of anti-racist feminist scholarship

126 A detailed historical account of the incorporated racism in the institutionalization of citizenship rights in the US is presented in Benjamin B. Ringer, We The People: Duality and America's Treatment of its Racial Minorities(New York: Routledge, 1983).

127 Colen (1990), 100.

128 Ibid, I01. 
over recent years. As in the polarized, yet interdependent, images of "true" (white) womanhood and Black womanhood in the ante-bellum South analyzed by Hazel Carby,129 the racialized images of women are often dependent upon each other, existing in a field of opposition, and antagonism, as well as hierarchy. At the same time, given the complex historical derivation of the many racial/ethnic images of women, each stereotype rarely exists "in a simple binary pattern of opposites."130

As witnessed in the routine use of stereotypes in the work of domestic placement agencies documented in this article, as well as in several other studies, racially and culturally specific notions of "femininity" play an important role in "racializing" a given labor market. Inscribed in various institutional mechanisms, these racial/gendered discourses aid in the work of relegating women of different "races" and ethnicities to specific occupations, in barring them fron entry into others, and in conditioning state and managerial strategies of control. Gatekeepers, both public and private, are important conveyers of differential racial/ethnic images of women, and play a key role in allocating those with the "appropriate" characteristics into "appropriate" occupations and attendant citizenship statuses.

Viewing citizenship globally, and as a phenomenon that draws upon racial/ethnic, gender and class distinctions, further addresses a growing concern within contemporary feminist literature with "difference" and the issue of unequal and oppressive relations between and among women.131 To date, little

129 Hazel Carby, Reconstructing Womanhood: The Emergence of the Afro-American Woman Novelist (New York: Oxford University Press, 1989).

130 Vron wale, Beyond the Pale: hihite women, Racism and History. (London: Verso, 1992), xvii.

I31 This is a vast and varied field, with little common points of reference other than the support for the expression of multiple identities within a feminist discourse. See for example, Trinh T. Minh-ha, Woman, Native, other (Bloomington: Indiana University Press, 1989); Marianne Hirsch and Evelyn Fox Keller (eds.), Conflicts in Feminism (New York: 
theoretical attention has been devoted to explaining the historical and structural specificity of various forms and types of "difference" and how they are constructed or transformed. Here it is suggested that differences in citizenship status that reflect the hegemony of advanced capitalist states, interact with racial/ethnic, gender and class differences to facilitate structural inequities between predominantly white women citizens and predominantly migrant (non-citizen) women of color.

Moreover, as we have demonstrated above, within the borders of capitalist states there is a specific role played by class "difference" which holds a structural and market-based imperative that tends to supercede and alter other features of shared or common identification.132 The household unit is subject to the imperative of class relations comparable in many respects to any workplace. As Judith Rollins has stated,

Clearly, the objective for most American employers, like that of employers all over the world, has been to extract as much work as possible while paying as little as possible. The arrangement between employer and worker is...first and foremost a class relationship. 133

However, the privatized nature of the household hides from public view the class dynamics which arise upon the

Routledge, Chapman and Hall, 1990); and Patricia J. Williams, The Alchemy of Race and Rights (Cambridge, Mass.: Harvard University Press, 1991).

132 For a further elaboration of the specificity of class relative to other forms of oppression in such a context, see Judy Fudge and Harry Glasbeek, "The Politics of Rights: A politics with Little Class," Social and Legal studies 1 (1992): 45-70. See also Eric Olin Wright, Classes (London: Verso, 1987 ; 1989).

133 Judith Rollins, "Ideology and servitude," in sanjek and Colen (1990), 77. See also Rollins (1985) for a more indepth examination of "how class and race inform [the] female-female work relationship both to the women involved and to the larger society" in the sphere of domestic service (7). 
employment of the domestic servant. The perpetuity of the exploitive conditions associated with in-home domestic service has meant that a practice "hauntingly close to serfdom"134 has become institutionalized in conditions of advanced capitalist liberal democractisis unequal assignment of rights is endemic to citizenship practices in general as they have matured in advanced capitalist states with established discourses of liberal ideology. The widespread acceptance in practice of abusive relations accorded to non-citizen domestic workers, coinciding with an ideological rejection of the implications of such abuse in official discourse, was starkly revealed in the recent events surrounding the aborted appointment of zoe Baird to the position of Attorney General. The January 1993 controversy over US President Bill Clinton's chosen nominee,drew international attention to the common practice among affluent American families of employing illegal aliens as "domestic help."135 In Canada, Third world domestic workers endure a minimum of two years of virtual bonded servitude, institutiiionalized through the federal government's foreign domestic program. The reason why the program continues to attract applicants despite these conditions is for "a shot at the prize of landed immigrant [permanent resident] status."136 Recent increased restrictions in entrance criteria for eligibility in the canadian foreign domestic program have augmented the numbers of women working illegally

134 Sutherland (1981), 121.

135Following her disclosure that she had knowingly hired tivo undocumented workers from Peru as domestic workers, zoe Baird withdrew her nomination for U.S. attorney. According to Stephen Hess of the Washington-based Brookings Institution, although Baird's offence "isn't like murder or arson and is something that is widely done and winked at, for the chief law enforcement officer it is not all right" (Maclean's Magazine, February 3, 1993, p.42). Part of the hostility to Baird's candidacy stemmed from the frustration felt by Americans struggling to pay for legal child care (Ibid.) 136 Macklin (1992), 685 . 
as an "under-society" of super-exploited domestics, cooks and nannies in a situation analogous to those of illegal alien domestics in the US.137

In an effort to justify abusive practices which are antithetical to an official discourse of "equality," domestic placement agencies, immigration authorities, and state 'femocrats' have all portrayed Third World migrant women entering through foreign domestic policy as beneficiaries of foreign aid.138 A formidable ideological hurdle, then, to the dismantling of a policy which in reality renders Third world women unfree wage laborers and non-citizens, is not only the argument that such a program is "needed by professional canadian women," but also the misguided view that it "helps Third World women." It is only by revealing how systemic practices render some relatively privileged women complicit in the reproduction of racial, ethnic, and other forms of inequities for other women that the real structural boundaries of oppression can be revealed, understood, and challenged.

137Alanna Mitchell, "New Rules Create Greater Nanny Shortage," The Globe and Mail Jan. 23, 1993. 138 Sedef Arat-Koc, "Immigration Policies, Migrant Domestic Workers and the Definition of Citizenship in Canada, "Paper delivered to the Immigration, Racism and Multiculturalism conference, University of Saskatchewan, Saskatoon (March 1991). 